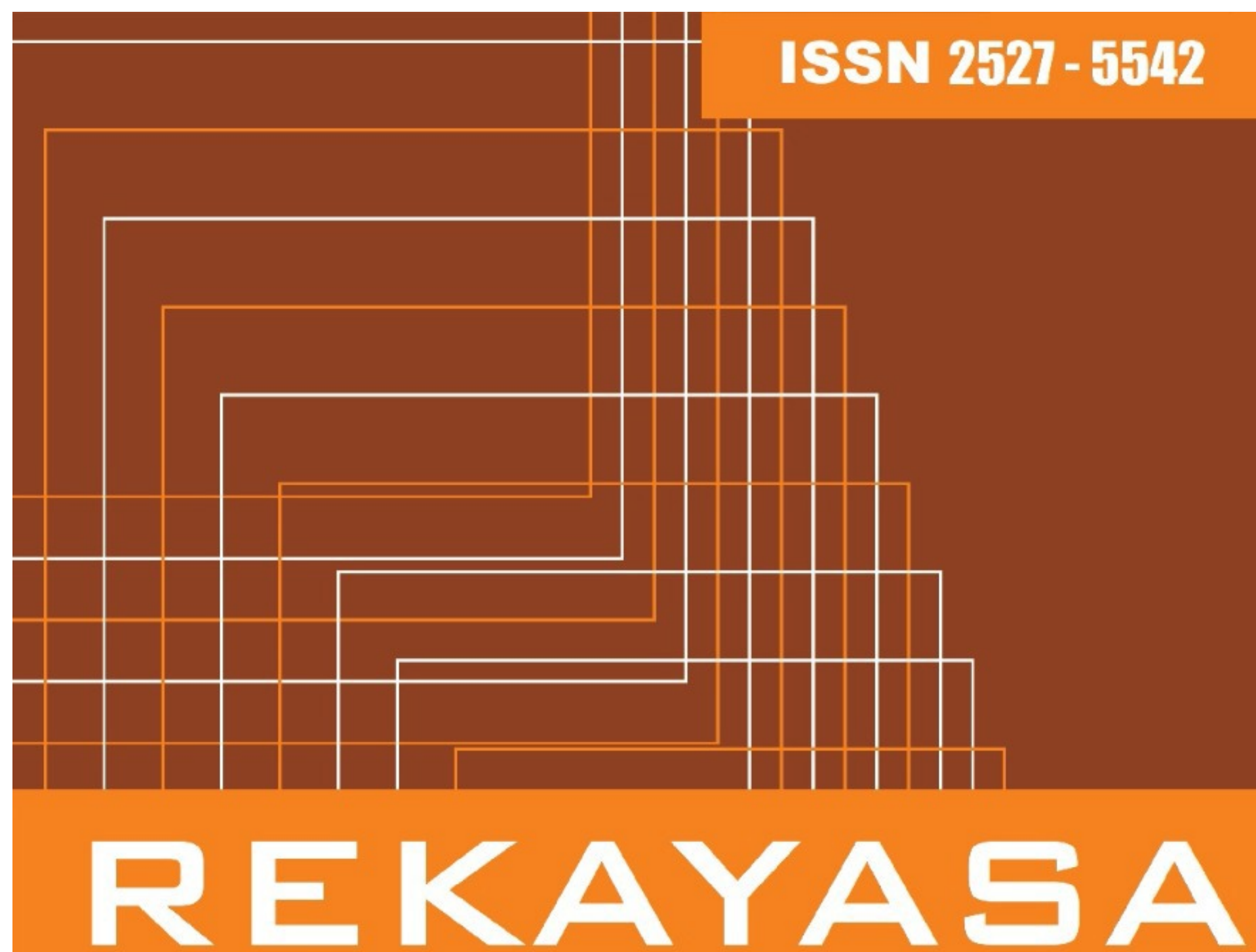

JURNAL TEKNIK SIPIL

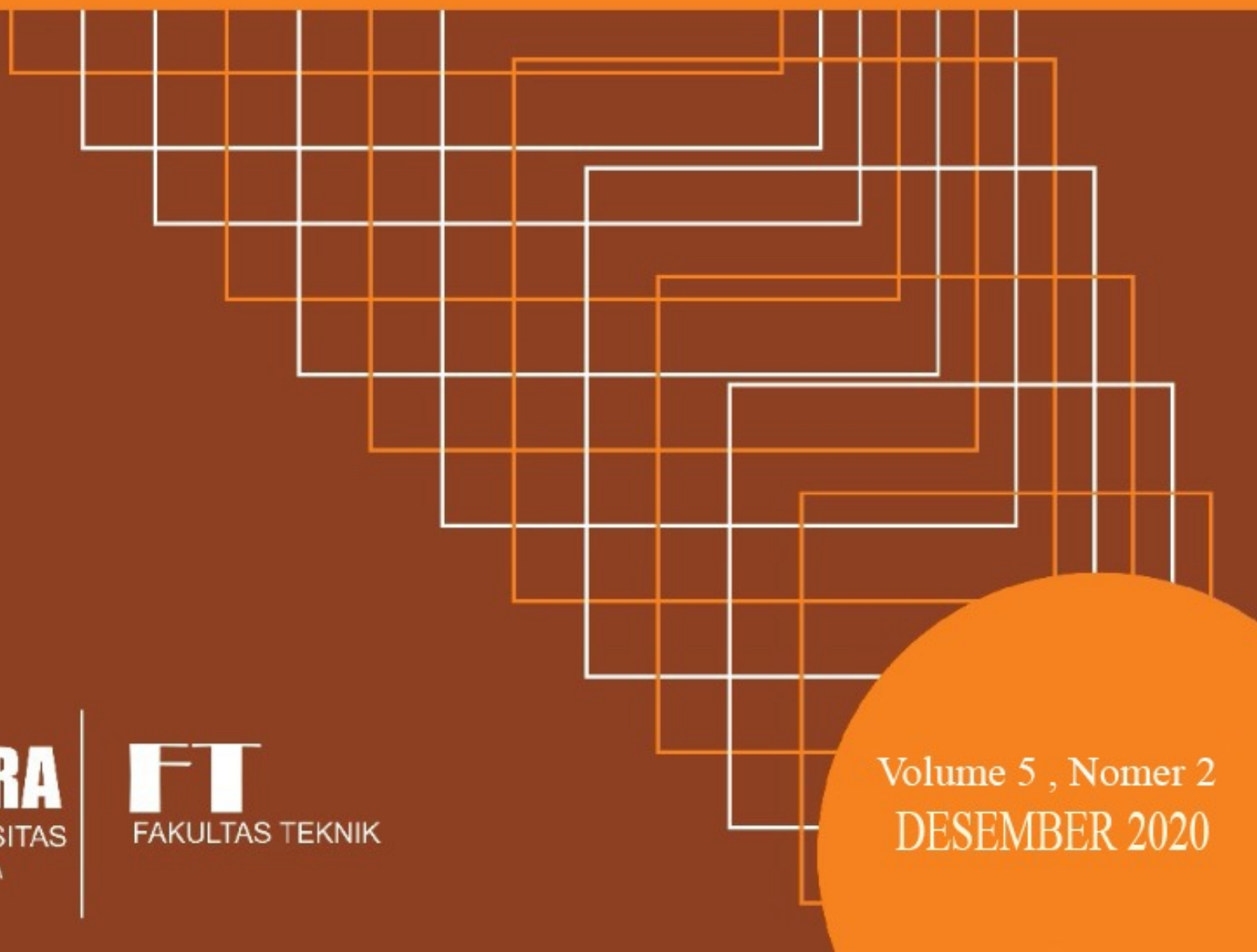




\section{REKAYASA TEKNIK SIPIL}

Media Publikasi Karya Ilmiah di Bidang Teknik Sipil

Volume 5, Nomer 2.

Desember 2020

\section{Penanggung Jawab :}

Ir. Moch. Hazin Mukti, MT., MM

\section{Mitra Bestari :}

Dr. Ir. Lalu Mulyadi, MT

Dr. Ir. Kustamar, MT

Dr. Ir. Subandiyah Azis, CES

Dr. Faisal Estu Yulianto, ST., MT.

Dr. Gusfan Khalik, ST., MT.

\section{Komite Pelaksana :}

Dedy Asmaroni, ST., MT.

Taurina Jemmy Irwanto, ST., MT.

Ahmad Fatoni ST., M.MT.

Aldi Setiawan, ST., MT.

Ahmad Fausi, ST.

\section{Komite Pelaksana :}

Fakultas Teknik - Universitas Madura

Jl. Raya Panglegur KM. 3,5 Pamekasan 69317

Telp. (0324) 322231 psw 114 Fax (0324) 327418

Email : Jurnal.rekayasa.unira@gmail.com 


\section{REKAYASA TEKNIK SIPIL}

Media Publikasi Karya Ilmiah di Bidang Teknik Sipil

Volume 5, Nomer 2.

Desember 2020

\section{DAFTAR ISI}

1. Analisis Keterbacaan Informasi Bahasa Inggris di Stasiun Madiun Armyta Puspitasari dan Arinda Leliana

2. Urgensi Technical Skill Bagi Tenaga Kerja Konstruksi Dalam Era Industri 4.0

Blima Oktaviastuti, Riana Nurmalasari, dan Fifi Damayanti

3. Evaluasi Tarif Angkutan Umum Lyn N Berdasarkan Biaya Operasional Kendaraan, Ability To Pay, Dan Willingness To Pay (Studi kasus: Angkot Lyn N, Rute Terminal Bratang - JMP, Kota Surabaya)

Abraham Kambuaya dan Theresia MCA

4. Kinerja Angkutan Umum Ag (Arjosari - Gadang) Pada Masa Pandemi Covid-19 Kota Malang

Rifky Aldila Primasworo dan Andreas Joni

5. Pengaruh Penerapan K3 (Keselamatan dan Kesehatan Kerja) Pada Pembangunan Laboratorium Komputer SMP It Al-Haromain, SMPS Darul Ulum, Dan SMP Badrul Ulum

Dedy Asmaroni dan Ahmad Fatoni 


\title{
Analisis Keterbacaan Informasi Bahasa Inggris di Stasiun Madiun
}

\author{
Armyta Puspitasari ${ }^{1}$ dan Arinda Leliana ${ }^{2}$ \\ ${ }^{1}$ Teknologi Bangunan dan Jalur Perkeretaapian, Politeknik Perkeretaapian Indonesia, Madiun \\ ${ }^{2}$ Manajemen Transportasi Perkeretaapian, Politeknik Perkeretaapian Indonesia, Madiun \\ E-mail:armyta@api.ac.id,arinda@ppi.ac.id.
}

\begin{abstract}
ABSTRAK: Stasiun Madiun merupakan salah satu stasiun Besar yang berada di bawah DAOP 7 wilayah Madiun yang melayani perjalanan antar kota. Madiun merupakan salah satu daerah yang menjadi tujuan baik turis lokal maupun internasional.Studi ini bertujuan untuk mengetahui keterbacaan informasi berbahasa Inggris yang ada di Stasiun Madiun, dan adanya penambahan informasi selama diberlangsungkannya tatanan new normal dalam mengatasi penyebaran Covid-19. Metode yang digunakan adalah deskriptif kualitatif. Data yang dikumpulkan melalui observasi, wawancara, dan dokumentasi kemudian dianalisis menggunakan metode triangulasi. Keterbacaan informasi berbahasa Inggris di Stasiun Madiun dinilai cukup baik dengan ketersediaan informasi baik menggunakan bahasa Indonesia maupun bahasa Inggris. Selama pandemic Covid-19, Stasiun Madiun menambahkan informasi yang berkaitan denganpencegahan penyebaran Corona virus. Informasi tambahan tersebut meliputi ruang isolasi, alur evakuasi calon penumpang dengan hasil rapid test menunjukkan reaktif, SOP pemeriksaan rapid test, dan persyaratan dan alur penumpang kereta api.
\end{abstract}

Kata Kunci : Keterbacaan, Informasi, , Stasiun Madiun

\section{PENDAHULUAN}

Stasiun kereta api berfungsi sebagai tempat kereta api berangkat maupun berhenti serta melayani naik turun penumpang, bongkar muat barang dan keperluan operasi kereta api. Stasiun dibedakan menjadi stasiun kecil, stasiun sedang, dan stasiun besar. Stasiun Madiun merupakan salah satu stasiun besar yang melayani perjalanan kereta api antar kota. Di dalam stasiun kereta api Madiun, terdapat beberapa fasilitas yang disediakan kepada calon penumpang. Dalam Peraturan Menteri Perhubungan Republik Indonesia Nomor PM 63 Tahun 2019 tentang Standar Pelayanan Minimum Angkutan Orang dengan Kereta Api pasal 5 ayat (1) menyatakan bahwa SPM di Stasiun Kereta Api mencakup, Keselamatan, Keamanan, Kehandalan, Kenyamanan, Kemudahan, dan Kesetaraan. Mengacu pada Standar Pelayanan Minimum tersebut, maka perlu adanya sistem informasi yang mempermudah para calon penumpang kereta api. Fasilitas-fasilitas yang ada di setiap stasiun yang menunjang kenyamanan dan keamanan para calon penumpang tentunya akan lebih mudah diketahui dengan adanya papan informasi tersebut. Papan informasi merupakan salah satu media yang efektif dan efisien dalam memberikan informasi terkait keamanan dan fasilitas yang ada di stasiun tersebut dibandingkan dengan media lainnya.

Madiun merupakan salah satu kota yang banyak dikunjungi wisatawan. Banyak destinasi yang dapat dikunjungi oleh para wisatawan seperti kuliner, wisata alam, dan tempat transit yang nyaman bagi para wisatawan baik domestik maupun internasional. Tidak jarang terdapat banyak turis asing yang singgah ke kota Madiun untuk berwisata dan urusan bisnis. Tentunya, kedatangan para turis internasional ke Madiun menggunakan berbagai macam moda transportasi, salah satu diantaranya adalah Kereta Api. Sebagai penunjang layanan yang ada di stasiun kereta api, tentu perlu adanya informasi bilingual yang digunakan.

Bahasa inggris merupakan bahasa internasional yang menjadi basic untuk berkomunikasi dengan para wisatawan asing. Dengan hal ini, maka informasi yang ada di Stasiun tidak hanya berbahasa indonesia, melainkan juga perlu adanya informasi berbahasa inggris untuk memudahkan para wisatawan baik domestik maupun internasional. Di masa Pandemi Covid 19 yang merajalela di seluruh penjuru daerah baik nasional maupun internasional, tentunya sangat berpengaruh bagi pelayanan yang ada di stasiun kereta api. Salah satunya untuk mencegah hal tersebut, adanya pembatasan jumlah kereta api yang beroperasi selama pandemi Covid-19. Dan dengan adanya tatanan new normal, kereta api merupakan salah satu pilihan moda transportasi yang digemari karena keamanan dan kenyamanannya selama pandemi ini. Tentunya ada beberapa fasilitas tambahan yang diberikan untuk menunjang kemudahan dan keamanan dalam hal kesehatan pada tatanan new normal untuk meminimalisir adanya penularan dan atau penyebaran virus Covid 19 kepada seluruh penumpang dan calon penumpang kereta api. Perlu adanya penelitian tentang keterbacaan informasi berbahasa inggris di Stasiun Madiun, dan melakukan analisis mendalam tentang adanya informasi dan fasilitas tambahan yang diberikan di Stasiun Madiun selama tatanan new normal.

\section{METODE PENELITIAN}

Penelitian ini merupakan penelitian kualitatif. Menurut Sugiyono (2011:9) metode kualitatif adalah metode dimana untuk meneliti pada objek alamiah, dimana peneliti adalah sebagai instrument kunci, teknik pengumpuln data dilakukan dengan cara triangulasi (gabungan). Analisis data bersifat induktif atau kualitatif, dan hasil penelitian lebih menekankan makna daripada generalisasi.

Metode pengumpulan data pada penelitian ini menggunakan teknik observasi, wawancara, dan dokumentasi. Observasi dilakukan untuk mengetahui ketersediaan informasi berbahasa Inggris di Stasiun Madiun. Apakah informasi berbahasa inggris pada stasiun Madiun telah sesuai dengan Standar Pelayanan Minimum yang telah ditetapkan oleh kementrian Perhubungan.

Teknik yang digunakan pada penelitian ini selain observasi, juga dilakukan wawancara. Moloeng (2010:186) mengungkapkan wawancara adalah percakapan dengan maksud tertentu percakapan itu 
dilakukan dengan dua belah pihak yaitu pewawancara (interviewer) dan terwawancara (interviewee) yang memberikan jawaban atas pertanyaan itu. Wawancara dilakukan untuk mengetahui lebih dalam tentang informasi berhasa Inggris yang tersedia di stasiun Madiun. Wawancara dilakukan kepada Customer Service dan calon penumpang yang ada di Stasiun Madiun.

Dokumen menurut Sugiono (2009:82) bisa berbentuk tulisan, gambar, atau karya-karya monumental dari seseorang. Dokumen yang berbentuk tulisan misalnya catatan harian, sejarah kehidupan (life histories), cerita, biografi, peraturan, kebijakan. Dokumentasi pada penelitian ini dilakukan untuk mengumpulkan bukti dan keterangan yang berupa informasi berbahasa Inggris dan membandingkan dengan Peraturan Menteri Nomor 63 Tahun 2019.

\section{PEMBAHASAN}

Pada penelitian ini, peneliti menganalisa terkait dengan keterbacaan informasi berbahasa inggris yang ada di Stasiun Madiun selama tatanan new normal selama Pademi Covid 19. Terkait dengan informasi berbahasa inggris tentang keselamatan yang ada di stasiun Madiun. Data yang diperoleh dari hasil observasi, wawancara, dan dokumentasi yang telah dilakukan, berikut ini pembahasan dan hasil analisisnya;
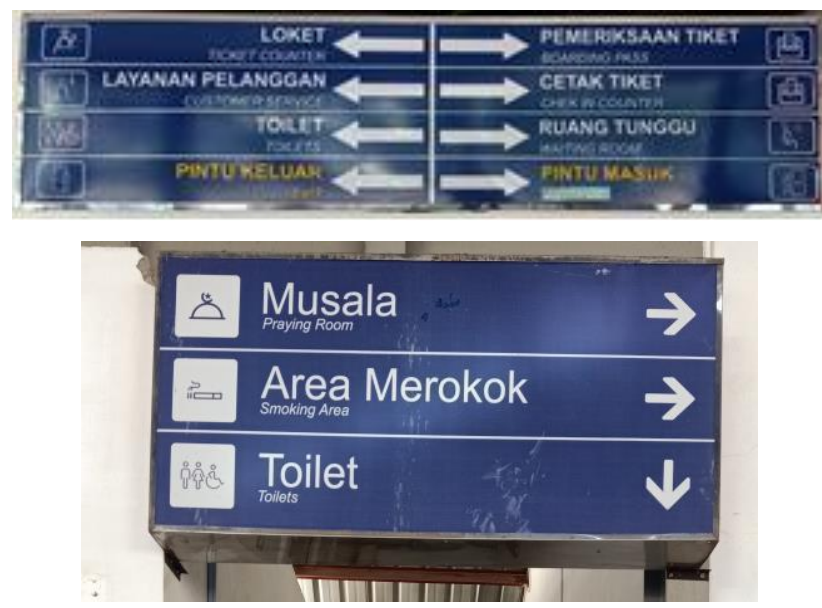

Gambar 1. Informasi di Stasiun Madiun

Gambar 1 menunjukkan adanya papan informasi berbahasa inggris di stasiun Madiun. Penempatan papan informasi tersebut sangatlah strategis dan dapat dilihat dengan mudah oleh calon penumpang kereta api yaitu di beberapa titik seperti di ruang tunggu dan tempat kedatangan calon penumpang di stasin madiun sebelum dilakukannya check in. Papan informasi tersebut juga dapat terbaca dengan jelas. Sesuai dengan PM 63 Tahun 2019 tentang Standar Pelayanan Minimum Angkutan Orang di Stasiun, penanda penunjuk arah dengan proporsi ukuran huruf/teks penanda lebih besar dari informasi lain. Papan informasi yang ada di stasiun madiun sudah memenuhi standar tersebut, dapat terbaca dengan jelas serta memiliki bahasa bilingual, bahasa indonesia dan bahasa inggris.
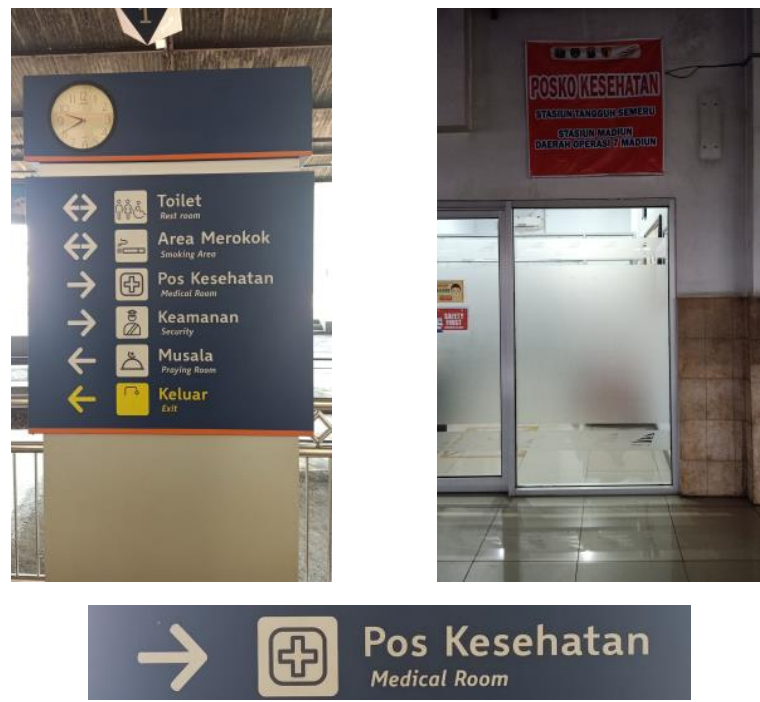

Gambar 2. Tanda Informasi fasilitas kesehatan

Pada petunjuk keselamatan yang ada di PM 63 tahun 2019, salah satunya adalah tanda dan informasi fasilitas kesehatan (Gambar 2) yang ada di stasiun madiun telah memenuhi syarat tersebut dengan adanya tanda pos kesehatan bilingual yang ditempatkan ditempat yang mudah terbaca. Papan informasi tersebut berada di pintu masuk keberangkatan calon penumpang kereta api. Sehingga fasilitas tersebut diberikan kepada calon penumpang kereta api yang telah melakukan proses check in (verifikasi data sebelum keberangkatan). Selain informasi tentang pos kesehatan, informasi lain terkait dengan keamanan berupa pos keamanan, kenyamanan yang mencakup adanya petunjuk arah tolite, area merokok, petunjuk arah tempat ibadah, dan arah keluar calon penumpang telah tersedia dan menggunakan translasi berbahasa inggris.

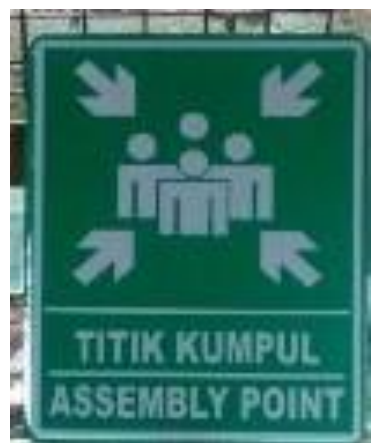

Gambar 3. Titik Kumpul/ Asembly point

Salah satu indikator adanya keamanan yang baik adalah dengan adanya titik kumpul (assembly point) seperti pada Gambar 3 yang tersedia pada stasiun besar. Hal ini untuk mencegah adanya kejadian darurat seperti gempa bumi dan kejadian darurat lainnya, sehingga para calon penumpang dapat berlindung dengan mencari titik aman yang ada di area stasiun tersebut. 


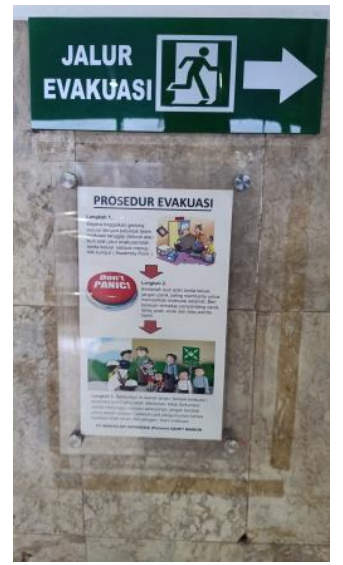

Gambar 4. Petunjuk Jalur dan Prosedur Evakuasi

Petunjuk jalur dan prosedur evakuasi merupakan indicator keselamatan yang ada di stasiun. Gambar 4 menunjukkan ketersediaan jalur dan prosedur evakuasi di area Stasiun Madiun. Terdapat beberapa titik penunjuk arah jalur evakuasi yang ada di dalam stasiun madiun. Ada sebanyak 5 penunjuk jalur evakuasi yang berkesinambungan menuju pintu keluar dan titik kumpul yang ada di stasiun. Namun, jalur evakuasi dan petunjuk keselatan belum menggunakan multi bahasa. Namun, dengan adanya gambar yang menunjukkan petunjuk berbahasa inggris, akan mempermudah calon penumpang asing yang ada di stasiun madiun.

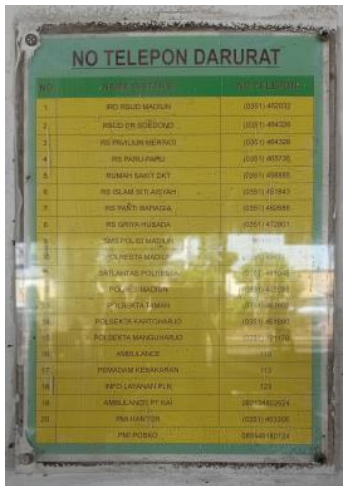

Gambar 5. Nomor telephone informasi layanan darurat

Pada gambar 5 menunjukkan nomor telepon informasi layanan darurat untuk menunjang keamanan dan keselamatan calon penumpang. Diantaranya nomor Rumah sakit yang ada di Madiun, kantor polisi/polsek/polres terdekat, ambulan, info layanan PLN, dan PMI. Terdapat 2 (dua) titik Nomor telepon darurat yang ada di dalam stasiun madiun. Namun, keduanya belum menggunakan bilingual, sehingga informasi tersebut hanya dapat dipahami oleh calon penumpang domestic. Namun akan lebih mudah jika penempatan papan informasi ditempatkan ditempat strategis dan tulisan yang lebih besar, sehingga mempermudah para calon penumpang untuk menemukan nomor telephone darurat yang ada di Stasiun Madiun.

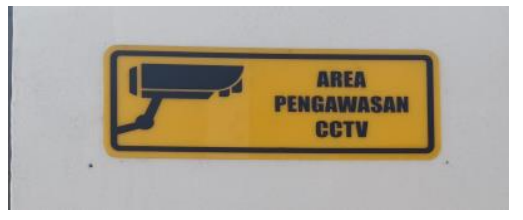

Gambar 6. Tanda adanya CCTV di area stasiun

Tanda adanya CCTV (Close Circuit Television) merupakan indicator keamanan di dalam stasiun. Gambar 6 menunjukkan stasiun Madiun dalam area pengawasan CCTV yang mana keamanan calon penumpang sangatlah dijaga.
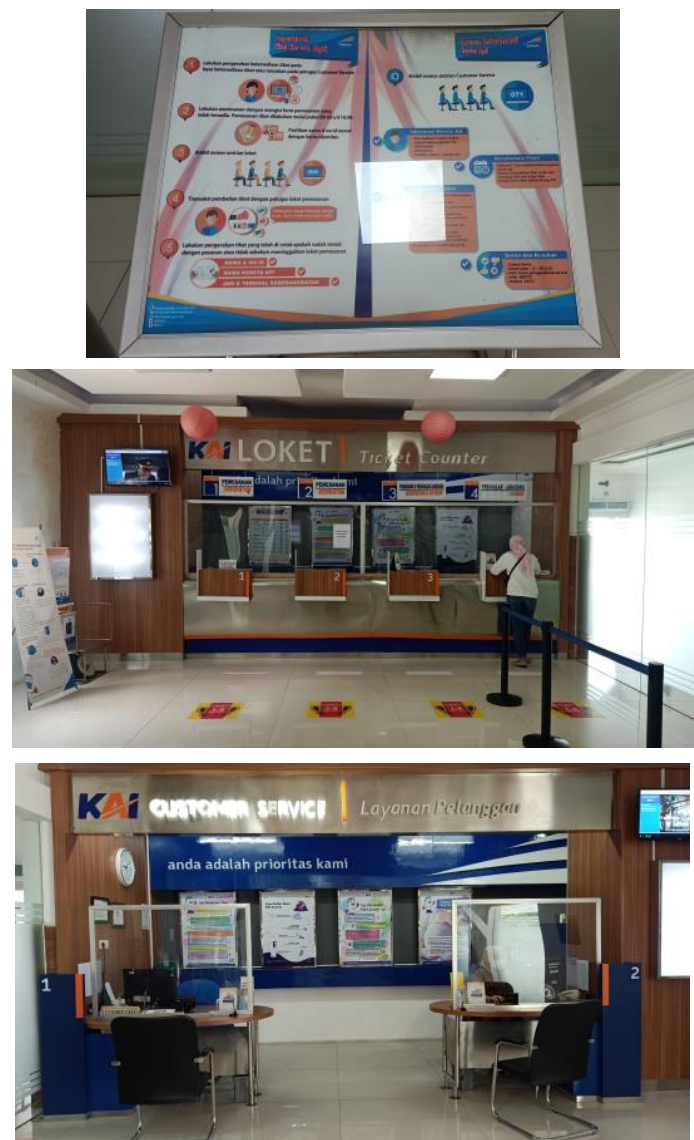

Gambar 7. Papan informasi tata cara pembelian manual dan layanan Customer Service

Kehandalan/keteraturan yang ada di stasiun yang menjadi indicator adalah dengan adanya papan informasi tata cara pembelian dan top up, informasi papan jadwal operasi, kedatangan dan keberangkatan kereta. Selain itu yang menjadi indicator kemudahan infomasi antara lain informasi perjalanan kereta api dan layanan pengaduan (Customer Service). Pada papan informasi (Gambar 7) tentang tatacara pembelian masih menggunakan bahasa Indonesia, sehingga informasi tersebut belum dapat menjangkau para turis asing saat melakukan pembelian tiket secara manual.

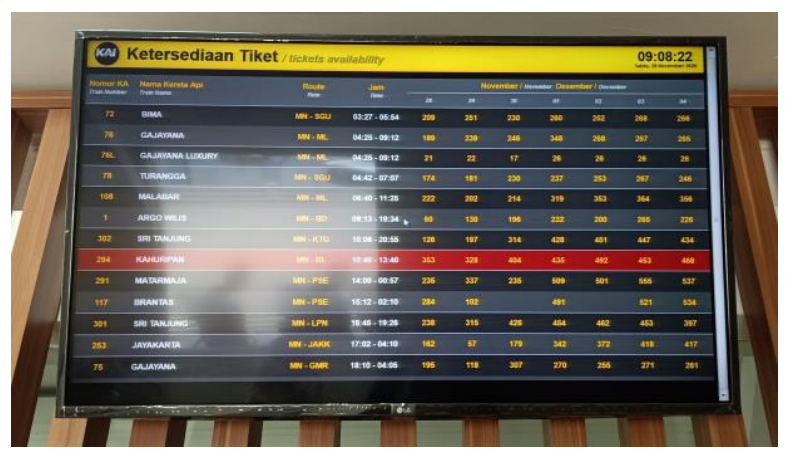

Gambar 8. Informasi papan jadwal operasi dan peta 


\section{jaringan pelayanan kereta api}

Informasi papan jadwal operasi dan ketersediaan tiket tersedia pada papan informasi yang tertera pada Gambar 8 (delapan). Adanya informasi bilingual mempermudah para calon penumpang untuk memahami jadwal dan ketersesiaan tiket yang beroperasi di Stasiun Madiun.

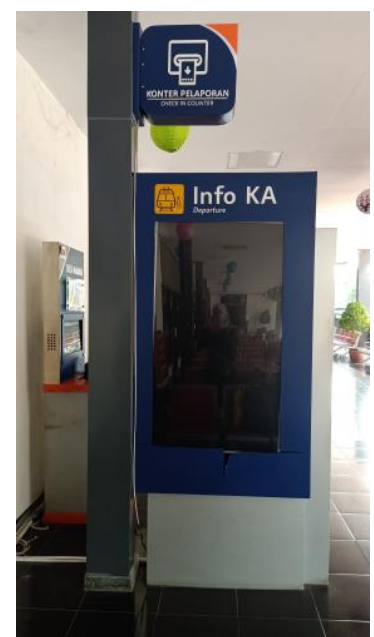

Gambar 9. Informasi kedatangan dan keberangkatan kereta

Informasi kedatangan dan keberangkatan kereta merupakan salah satu indikator kehandalan/keteraturan yang ada di stasiun Madiun (Gambar 9). Informasi yang diberikan sudah memenuhi standar dengan adanya papan informasi dan menggunakan bilingual, baik bahasa Indonesia maupun bahasa inggris, sehingga mempermudah para calon penumpang baik domestic maupun internasional.
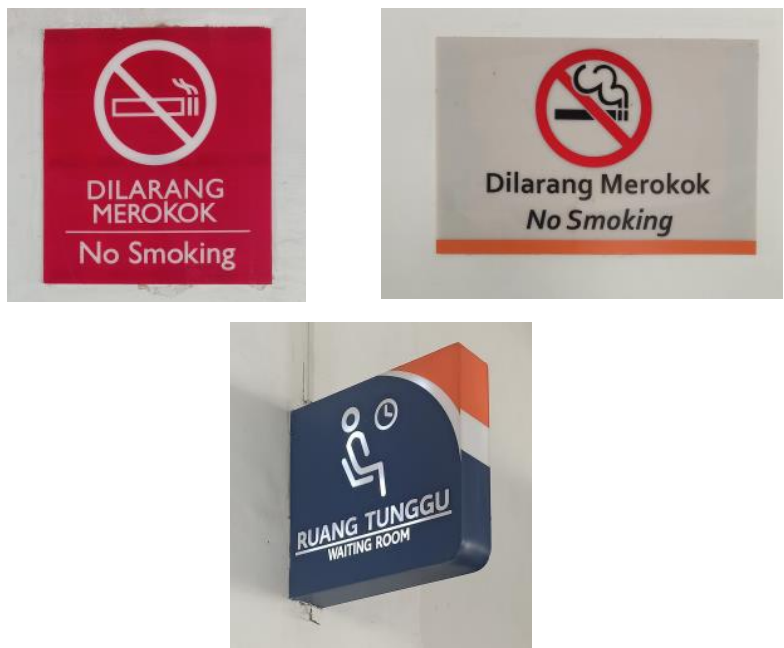

Gambar 10. Tanda himbauan larangan merokok, area boarding dan ruang tunggu

Untuk menunjang kenyamanan para calon penumpang yang ada di stasiun madiun, pihak operator memberikan ruang tunggu penumpang dan ruangan terbuka untuk para calon penumpang yang ingin merokok seperti pada Gambar 10. Tentunya area stasiun secara keseluruhan merupakan area bebas asap rokok sehingga memberikan kenyamanan pada calon penumpang yang ada di Stasiun madiun. Informasi tersebut dipermudah dengan adanya tanda larangan merokok di area stasiun madiun.

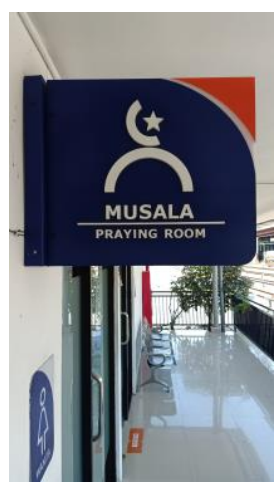

Gambar 11. Petunjuk arah tempat ibadah

Petunjuk informasi tempat ibadah merupakan salah satu indicator kehandalan/keteraturan di area stasiun Madiun. Terdapat papan informasi di tempat stategis yang menunjukkan dimana tempat ibadah berada (Gambar 11), dan dimana tempat ibadah tersebut dapat terlihat jelas dengan adanya informasi yang menggunakan 2 bahasa, baik bahasa Indonesia maupun inggris.

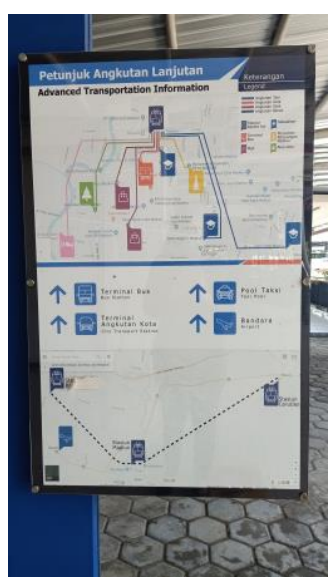

Gambar 12. Informasi angkutan lanjutan/integrase transportasi lain

Pada Gambar 12 terdapat papan informasi angkutan lanjutan/integrase transportasi lain di stasiun Madiun terletak pada arah sebelum keluar stasiun. Hal ini memudahkan para penumpang yang dating/turun di stasiun Madiun untuk melakukan perjalanan dan berpindah ke moda transportasi lain yang ada di kota Madiun meliputi Terminal Bus, Terminal angkutan kota, Pool taksi, stasiun dan bandara terdekat dengan kota Madiun. Pada petunjuk angkutan lanjutan ini juga terdapat denah/layout kota Madiun dan tempat pariwisata yang ada di Kota madiun. Dengan adanya petunjuk angkutan lanjutan dengan menggunakan bilingual memberikan kemudahan kepada penumpang kereta api yang datang di Stasiun Madiun baik penumpang domestic, maupun internasional. 

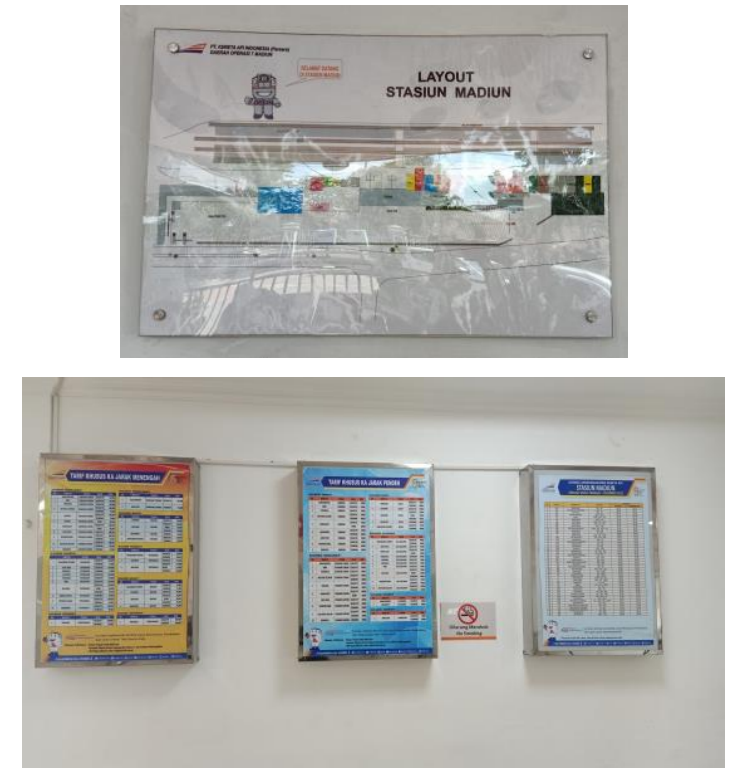

Gambar 13. Informasi pelayanan berupa denah/layout stasiun, nama stasiun, jadwal operasi kereta api, tarif kereta api

Untuk memberikan kemudahan kepada calon penumpang yang ada di stasiun madiun, informasi pelayanan berupa denah/layout stasiun, nama stasiun, jadwal operasi kereta api, tarif kereta api telah tersedia sesuai dengan SPM yang berlaku seperti yang terdapat pada Gambar 13.
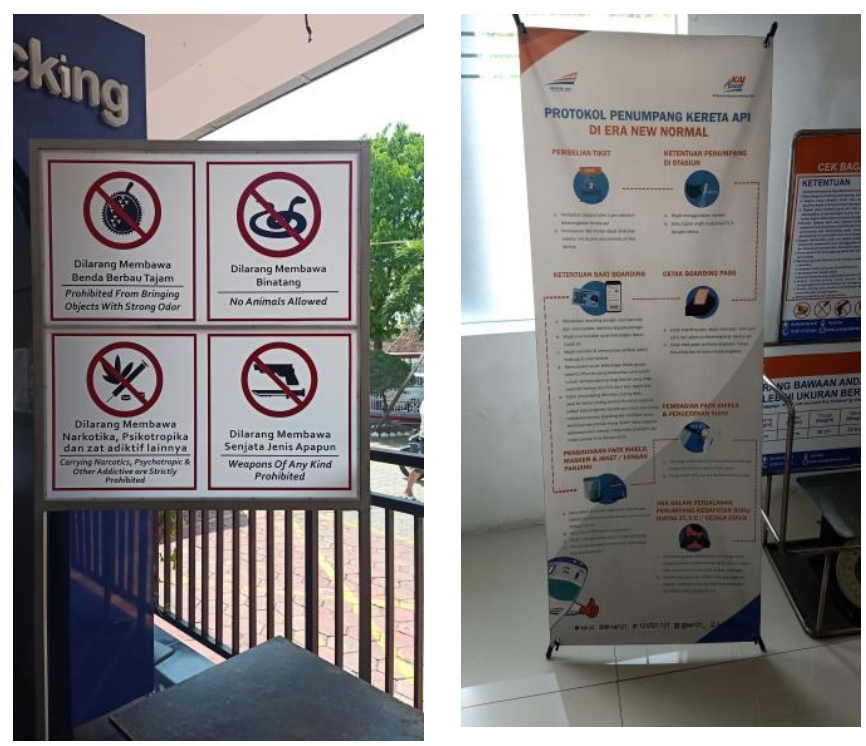

Gambar 14. Informasi himbauan

Gambar 14 memberikan informasi papan himbauan merupakan informasi tambahan yang dibutuhkan untuk calon penumpang kereta api agar memudahkan untuk mengetahui himbauan yang menjadi aturan dan tata cara selama menggunakan moda transportasi kereta api. Di stasiun Madiun terdapat beberapa himbuan tentang apa saja yang tidak boleh dibawa selama menggunakan moda kereta api demi menjaga kenyamanan dan keamanan para penumpang dengan menggunakan 2 bahasa. Serta ada informasi tambahan selama tatanan new normal untuk mencegah penyebaran virus Covid-19. Informasi protocol penumpang kereta api di era new normal masih menggunakan bahasa Indonesia, belum adanya informasi protocol penumpang berbahasa inggris yang ada di Stasiun Madiun.

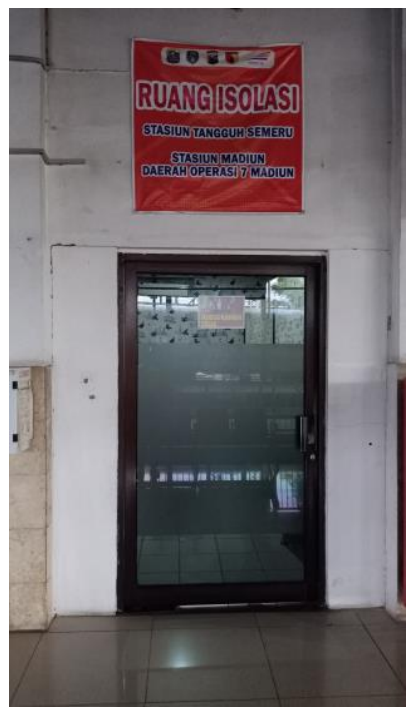

Gambar 15. Ruang Isolasi untuk Suspect Covid 19

Selain informasi himbauan protokol penumpang kereta api, stasiun Madiun memberikan petunjuk informasi terkait dengan ruang isolasi untuk calon penumpang yang menjadi suspect Covid 19 (Gambar 15). Berdasarkan wawancara dengan petugas Stasiun Madiun, Ruangan yang sebelumnya menjadi ruang laktasi berubah fungsi menjadi ruang isolasi untuk suspect Covid 19. Terdapat 2 (dua) ruang untuk suspect Covid 19. Satu ruangan berada di bagian luar Stasiun Madiun, sedangkan satu lagi berada di ruang tunggu calon penumpang Stasiun Madiun untuk menangani kejadian darurat jika ada yang terindikasi suspect Covid-19 dari calon penumpang yang melakukan Rapid di Stasiun Madiun dan penumpang yang datang dan turun dari kereta api. Dikarenakan keterbatasan ruangan yang ada di stasiun Madiun dan masih adanya kegiatan renovasi yang dilakukan di Stasiun Madiun.
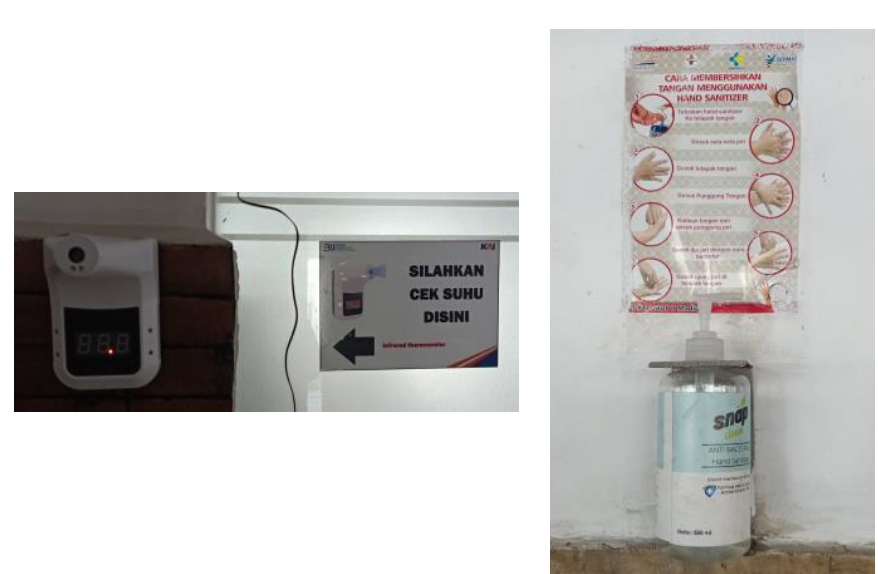

Gambar 16. Informasi Check suhu dan penggunaan Hand Sanitizer

Selama era new normal, protokol kesehatan haruslah dilakukan, diantaranya adalah pengecekan suhu badan, serta penggunaan hand sanitizer. Stasiun Madiun melakukan protokol kesehatan selama Pandemi Covid-19 dengan menyediakan fasilitas pengecekan suhu madiri, dan menempatkan himbauan untuk mencuci tangan dan menggunakan hand sanitizer dan cara penggunaannya 
agar mencegah penularan Covid-19 kepada para pengguna moda transportasi kereta api (Gambar 16).
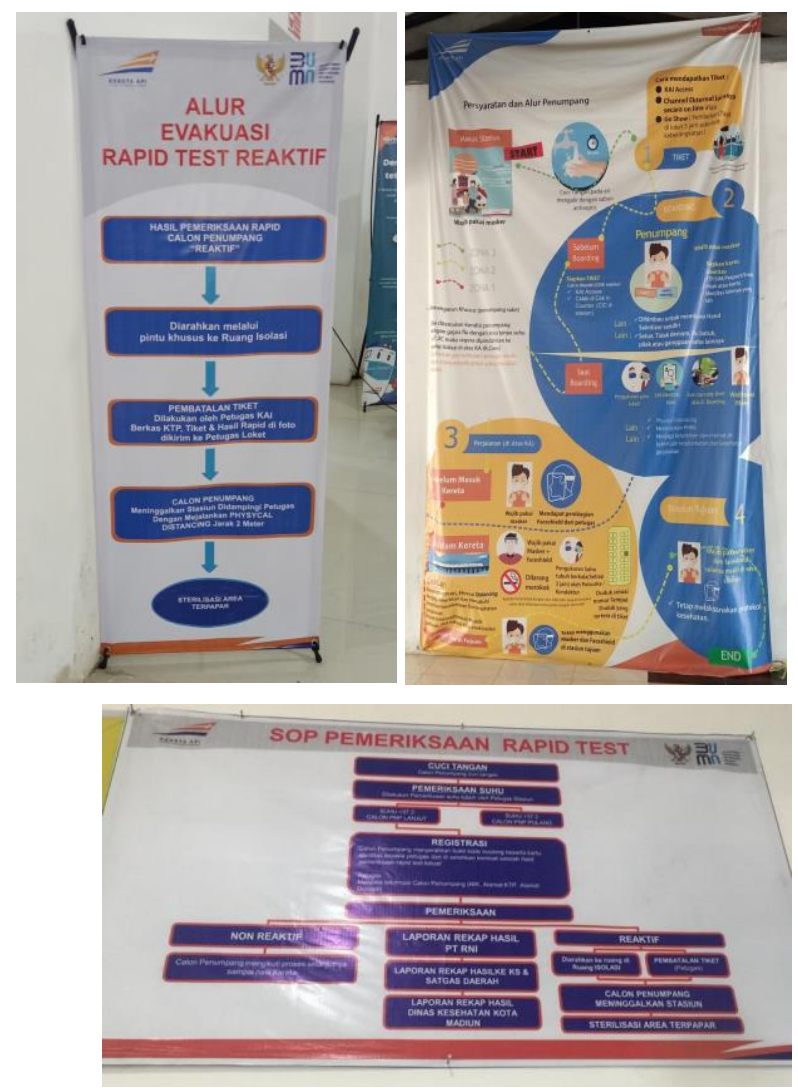

Gambar 17. SOP Penanganan Covid 19

Sebagai penunjang berlakunya tatanan new normal, stasiun Madiun memberikan fasilitas berupa test rapid kepada calon penumpang yang akan bepergian menggunakan moda transportasi kereta api. Hal ini sebagai wujud dukungan pihak KAI kepada pemerintah untuk mencegah penyebaran Covid-19. Dengan adanya hal tersebut, di Stasiun Madiun terdapat informasi terkait dengan alur evakuasi calon penumpang dengan hasil rapid test menunjukkan reaktif, SOP pemeriksaan rapid test, dan persyaratan dan alur penumpang kereta api (Gambar 17). Informasi tersebut sangat dibtuhkan bagi calon penumpang yang ingin menggunakan moda transportasi kereta api, hanya saja dikarenakan informasi tersebut tersedia hanya menggunakan bahasa Indonesia, maka akan sulit bagi para penumpang internasional untuk memahami informasi tersebut.

\section{KESIMPULAN}

Berdasarkan analisis data dan pembahasan yang telah dilakukan, maka dapat ditarik kesimpulan untuk keterbacaan informasi berbahasa Inggris di Stasiun Madiun dinilai cukup baik dengan ketersediaan informasi baik menggunakan bahasa Indonesia maupun bahasa Inggris, namun ada beberapa informasi yang hanya berbahasa indonesia. Adapun informasi yang perlu adanya penambahan bahasa Inggris antara lain petunjuk jalur evakuasi, nomor telephone darurat, area pengawasan CCTV, tata cara pembelian tiket manual, dan layout Stasiun Madiun. Selama pandemic Covid-19, Stasiun Madiun menambahkan informasi yang berkaitan dengan pencegahan penyebaran Corona virus. Informasi tambahan tersebut meliputi ruang isolasi, alur evakuasi calon penumpang dengan hasil rapid test menunjukkan reaktif, SOP pemeriksaan rapid test, dan persyaratan dan alur penumpang kereta api.

\section{Daftar Pustaka}

Aristantie, Fiki. (2011). Karya Tugas Akhir Perancangan Sign System Taman Satwa Taru Jurug. Surakarta : Universitas Sebelas Maret.

Baines, Phil. (2008). Sign: Lettering in the Environtment. London : Laurence King Publishing.

Creswell, John W. (2010). Research Design, Pendekatan Kualitatif, Kuantitatif, dan Mixed. Yogyakarta : Pustaka pelajar.

Leliana, Arinda., Widyastuti, Hera. (2018). Analisis Kepuasan Penumpang Terhadap Kinerja Pelayanan Di Stasiun Madiun. Teknologi Penerbangan, ISSN : 2548-8090 e-ISSN : 2548-8104. 2(2), 43-48.

Moleong, Lexy J. (2010). Metodologi Penelitian Kualitatif. Bandung : PT Remaja Rosdakarya Offset.

Peraturan Menteri Nomor PM 63 Tahun 2019 tentang Standar Pelayanan MinimumAngkutan Orang Dengan Kereta Api, Jakarta.

Sugiyono. (2013). Metode Penelitian Kuantitaif, Kualitatif, dan R \& D. Bandung : ALFABETA. 


\title{
URGENSI TECHNICAL SKILL BAGI TENAGA KERJA KONSTRUKSI DALAM ERA INDUSTRI 4.0
}

\author{
Blima Oktaviastuti ${ }^{1}$, Riana Nurmalasari ${ }^{2}$, dan Fifi Damayanti ${ }^{3}$ \\ ${ }^{1}$ Program Studi Teknik Sipil, Fakultas Teknik, Universitas Tribhuwana Tunggadewi, Malang \\ ${ }^{2}$ Jurusan Teknik Mesin, Fakultas Teknik, Universitas Negeri Malang \\ ${ }^{3}$ Program Studi Teknik Sipil, Fakultas Teknik, Universitas Tribhuwana Tunggadewi, Malang \\ E-mail: blima.oktavia90@gmail.com,riana.nurmalasari.ft@um.ac.id,fifidamayanti197408@yahoo.co.id
}

\begin{abstract}
ABSTRAK: Tulisan ini bertujuan untuk memaparkan kajian tentang: (1)tenaga kerja konstruksi; (2) technical skill; dan (3)pentingnya technical skill bagi tenaga kerja konstruksi. Kesimpulan yang diperoleh dari kajian ini bahwa, tenaga kerja yang kompeten secara langsung memiliki technical skill mumpuni dalam melaksakan pekerjaannya. Perkembangan pembangunan infrastruktur di Indonesia semakin banyak membutuhkan tenaga kerja dengan technical skill mumpuni sesuai kompetensi keahliaannya. Kebutuhan tenaga kerja konstruksi menjadi hal yang utama. Perlunya pengembangan dan penerapan technical skill sejak di bangku sekolah atau lembaga pelatihan, diharapkan dapat membiasakan serta membekali siswa dengan technical skill sebelum memasuki dunia kerja.
\end{abstract}

\section{Kata Kunci: Konstruksi; Tenaga Kerja; Technical Skill}

\section{PENDAHULUAN}

Kemajuan ilmu pengetahuan dan teknologi dewasa ini mengalami perkembangan pesat. Hal ini turut andil dalam perkembangan industri atau jasa konstruksi Indonesia secara tidak langsung. Sebagai contoh banyak proyek pembangunan yang dilaksanakan oleh pemerintah maupun pihak swasta dengan berbagai teknologi dan inovasi yang ditawarkan. Rencana Pembangunan Jangka Panjang Nasional (RPJPN) tahun 2005-2025 juga diarahkan untuk lebih memantabkan pembangunan secara menyeluruh di berbagai bidang (Kementerian Bappenas, 2017).

Penekanan pembangunan bertujuan untuk mencapai daya saing kompetitif pada perekonomian dengan berlandaskan keunggulan Sumber Daya Manusia (SDM) dan Sumber Daya Alam (SDA) berkualitas, dengan diimbangi kemampuan IPTEK yang terus meningkat. Konstruksi juga merupakan sektor perekonomian yang sangat penting untuk menghasilkan suatu produk bangunan, baik sebagai infrastruktur maupun properti (Taufik, A.I., 2012:216).

Peningkatan kualitas jasa konstruksi telah tertuang dalam Undang-Undang Nomor 18 Tahun 1999 tentang Jasa Konstruksi (UUJK). Perkembangan pesat tersebut diharapkan dapat mengembangkan peran serta jasa konstruksi nasional agar meningkatkan kualitas hasil kerja konstruksi. Salah satu faktor peningkatan kualitas tersebut dengan adanya peran serta tenaga kerja konstruksi yang kompeten.

Memasuki era industri 4.0 secara tidak langsung memberikan dampak signifikan pada perkembangan ekonomi di Indonesia. Sektor jasa konstruksi juga tidak lepas terkena dampaknya. Peran serta tenaga kerja menjadi salah satu kunci keberhasilan pelaksanaan suatu proyek jasa konstruksi. Berdasarkan artikel medan bisnis oleh Pasaribu (2016), dibutuhkan sedikitnya 750.000 orang tenaga kerja konstruksi bersertifikat ahli muda, madya dan utama serta tenaga kerja konstruksi bersertifikat terampil kelas satu, kelas dua dan tiga.
Dilanjutkan artikel sindo oleh Glienmourinsie (2015) menyatakan bahwa Indonesia memiliki jumlah tenaga kerja konstruksi yang cukup banyak, namun sebagian besar belum bersertifikasi yang mengakibatkan investor asing lebih memilih mendatangkan tenaga kerja dari luar negeri. Data tersebut menunjukkan bahwa Indonesia masih kekurangan tenaga kerja yang ahli. Tenaga kerja Indonesia harus memiliki technical skill yang mumpuni agar dapat bersaing dengan tenaga kerja luar negeri.

Berdasarkan uraian permasalahan diatas, maka tulisan ini bertujuan untuk memaparkan kajian tentang: (1) pekerja konstruksi, (2) technical skill, dan (3) pentingnya technical skill bagi tenaga kerja konstruksi.

\section{TENAGA KERJA KONSTRUKSI}

Simanjuntak (1998), tenaga kerja mencakup penduduk yang sudah atau sedang bekerja, yang sedang mencari pekerjaan dan yang melakukan kegiatan lain seperti bersekolah dan mengurus rumah tangga. Husni, L. (2003) menyatakan bahwa tenaga kerja adalah penduduk dalam usia kerja (berusia 15-64 tahun) atau jumlah penduduk dalam suatu negara yang dapat memproduksi barang dan jasa jika ada permintaan terhadap tenaga kerja mereka dan jika mereka mau berpartisipasi dalam aktifitas tersebut. Pengertian tenaga kerja menurut Undang-undang Republik Indonesia No. 13 Tahun 2003 tentang ketenagakerjaan adalah setiap orang yang mampu melakukan pekerjaan guna menghasilkan barang dan/atau jasa baik untuk memenuhi kebutuhan sendiri maupun masyarakat.

Saputri dan Rejekiningsih (2011) tenaga kerja dibagi dalam dua kelompok yaitu angkatan kerja dan bukan angkatan kerja. Angkatan kerja adalah penduduk dalam usia kerja yang terlibat atau berusaha untuk terlibat dalam kegiatan produktif yaitu memproduksi barang dan jasa. Angkatan kerja terdiri dari golongan bekerja serta golongan menganggur dan mencari pekerjaan. Bukan angkatan kerja adalah penduduk dalam usia kerja yang tidak bekerja, tidak mempunyai pekerjaan dan sedang 
tidak mencari pekerjaan. Bukan angkatan kerja terdiri dari golongan yang bersekolah, golongan yang mengurus rumah tangga dan golongan lain-lain atau penerima pendapatan. Ketiga golongan dalam kelompok ini sewaktu-waktu dapat menawarkan jasanya untuk bekerja. Oleh sebab itu, kelompok ini sering juga dinamakan sebagai angkatan kerja potensial (potensial labor force).

Ukuran produktivitas dalam pekerjaan yang sering diamati adalah pelakunya (tenaga kerja). Haryadi, B. (2010), kompetensi tenaga kerja konstruksi harus dapat ditunjukan secara realitas, legalitas dan akademik, serta tenaga kerja harus memiliki kompetensi dan bersertifikat, sedangkan untuk meningkatkan kompetensi tenaga kerja konstruksi dapat dilakukan dengan banyak melakukan pelatihan-pelatihan.

Berdasarkan UU No.13 Tahun 2003 Tentang Ketenagakerjaan, fungsi dan tugas-tugas tenaga kerja berdasarkan kehaliannya meliputi: (1)Mandor adalah orang yang mempunyai keahlian dalam bidang tertentu sesuai dengan jenis pekerjaan tertentu. Mandor membawahi langsung pekerja-pekerja atau tukangtukang; (2)Kepala tukang adalah orang yang mempunyai keahlian dalam bidang pertukangan untuk jenis pekerjaan tertentu dan memberi petunjuk-petunjuk kepada para tukang yang berhubungan dengan jenis pekerjaan tersebut; (3)Tukang adalah orang yang langsung mengerjakan pekerjaan dilapangan dalam bidang tertentu sesuai petunjuk kepala tukang. Orang-orang ini biasanya memiliki sedikit keterampilan; (4)Pekerja (buruh) adalah orang yang membantu tukang atau kepala tukang untuk semua jenis pekerjaan tanpa harus memiliki keahlian atas pekerjaan tertentu.

Pekerjaan di bidang konstuksi disamping menghasilkan jasa (misal menggambar denah bangunan) juga dapat menghasilkan barang (misal material bangunan keramik). Tidak hanya di bidang konstruksi, pekerjaan yang lain juga selalu membutuhkan skill yang mumpuni. Jika tenaga kerja tidak memiliki bekal skill yang mumpuni, maka akan kalah saing dengan tenaga kerja yang memiliki skill. Skill dijadikan tolok ukur utama dikarenakan dapat meningkatkan produktivitas suatu pekerjaan. Mengingat sudah memasuki era industri 4.0, maka tidak mengherankan jika persaingan dalam mencari pekerjaan semakin selektif, utamanya untuk pekerja konstruksi.

\section{TECHNICAL SKILL}

Technical skill merupakan bagian dari kompetensi yang harus dimiliki oleh tenaga kerja. Undang-Undang (UU) No. 13 tahun 2003 tentang Ketenagakerjaan menyebutkan bahwa kompetensi adalah kemampuan kerja setiap individu yang mencakup aspek pengetahuan, keterampilan dan sikap kerja yang sesuai dengan standar yang ditetapkan. Hakikat kompetensi merupakan perpaduan dari pengetahuan, keterampilan, nilai dan sikap yang direfleksikan dalam kebiasaan berpikir dan bertindak.

Mulyasa (2013:67) menggolongkan beberapa aspek yang terkandung dalam konsep kompetensi meliputi: (1) pengetahuan (knowledge); (2) pemahaman (understanding); (3) kemampuan (skill); (4) nilai (value); (5) sikap (attitude); dan (6) minat (interest).

Maman (Fernando,dkk., 2015:586) technical skill merupakan kecakapan menangani atau memecahkan suatu masalah melalui penggunaan peralatan, prosedur, metode, dan teknik dalam proses operasional, terutama menyangkut dengan pekerjaan yang berhubungan alat-alat yang harus digunakan dalam menyelesaikan pekerjaan. Technical skill diperlukan untuk menangani gangguan pada pekerjaan yang disebabkan oleh kerusakan peralatan, kelemahan kualitas, kecelakaan, keterbatasan material, dan masalah-masalah koordinasi.

Nurmalasari, R., dkk. (2019); Oktaviastuti, B., dkk. (2018) Sekolah Menengah Kejuruan (SMK) memberikan pelajaran berupa teori dan praktek sesuai kompetensi yang telah dipilih oleh siswa. Keberadaannya sangat membantu dalam membekali calon tenaga kerja konstruksi, disamping adanya balai latihan kerja yang dinaungi oleh pemerintah.

\section{PENTINGNYA TECHNICAL SKILL BAGI TENAGA KERJA KONSTRUKSI}

Oktaviastuti, B., dkk. (2016) kepemilikan tenaga kerja yang kompeten dan memiliki technical skill yang mumpuni, secara tak langsung meningkatkan produktivitas suatu negara. Tenaga kerja dengan technical skill yang kompeten sesuai bidangnya, memiliki nilai lebih dibandingkan dengan yang tidak.

Tenaga kerja yang memiliki technical skill, cenderung memiliki tingkat produktivitas lebih unggul daripada yang tidak memiliki technical skill. Hal ini secara langsung dapat memberikan keuntungan terhadap industri jasa konstruksi. Oleh karenanya, technical skill sangat dibutuhkan tenaga kerja saat melaksanakan pekerjaannya. Jika tenaga kerja tidak memiliki technical skill, sudah jelas akan kalah saing dengan yang memiliki. Apalagi di era industri 4.0 dengan saingan yang tidak hanya berasal dari dalam negeri.

\section{KESIMPULAN}

Technical skill dapat diperoleh melalui pendidikan, pelatihan motivasi, update teknologi, dan berbagai usaha kelompok lainnya. Penerapan technical skill pada sektor jasa konstruksi, secara tidak langsung akan berpengaruh pada peningkatan produktivitas tenaga kerja. Tenaga kerja yang kompeten akan dibekali technical skill mumpuni sesuai keahliannya. Pembekalan dapat melalui balai latihan kerja dan menambah kuota pendidikan di bidang kejuruan. Di Indonesia sendiri, masih perlu pengembangan dan penerapan technical skill sejak di bangku sekolah (utamanya untuk sekolah kejuruan).

\section{DAFTAR PUSTAKA}

Fernando, Z.A., Inra, A., dan Yustisia, H. 2015. Kesiapan Mahasiswa Program Studi Teknik Sipil dan Bangunan di Bidang Teknik Sipil. CIVED ISSN 2302-3341. 3(1): 584-590 
Glienmourinsie, Disfiyant. 2015. Sebagian Besar Tenaga Kerja Konstruksi Belum Bersertifikasi, (Online), https://ekbis.sindonews.com, diakses 10 November 2020.

Haryadi, Bada. 2010. Kompetensi Tenaga Kerja Konstruksi Dalam Menghadapi Era Liberalisasi. Jurnal Inersia. 6(1): 33-40.

Husni, L. 2003. Hukum Ketenagakerjaan Indonesia. Jakarta: PT. Raja Grafindo Persada.

Kementerian Bappenas. 2017. Dokumen Perencanaan dan Pelaksanaan RPJPN 2005-2025. (Online) https://www.bappenas.go.id, diakses 15 November 2020 .

Kementerian PUPR RI. 2015. Pasar Konstruksi Indonesia Besar, Jumlah Insinyur Masih Kurang. (online), http://www.pu.go.id., diakses 12 November 2020.

Kemenperin RI. 2003. Undang-Undang Keternagakerjaan: Pasal 86 Nomor 13.

Kemenperin RI. 2003. Undang-Undang Keternagakerjaan: Pasal 1 Nomor 13 ayat 10

Mulyasa. 2013. Pengembangan dan Implementasi Kurikulum 2013. Bandung: Remaja Rosdakarya.

Nurmalasari, R., Oktaviastuti, B., dan Nafiah, A. 2019. The Role and Teacher's Understanding in Implementing Curriculum on Vocational High School. JPP (Jurnal Pendidikan dan Pembelajaran). 26(2): 57-59.

Oktaviastuti, B., Dardiri, A., Nindyawati, and Nurmalasari, R. 2016. The correlation between industrial support and vocational attitude toward the increasing of student's technical skill on building drawings engineering. Jurnal AIP Conference Proceedings. 1778(1): 030039.

Oktaviastuti, B., dan Indana, L. 2018. Warna Pembelajaran PSG: Peningkatan Technical Skill Siswa SMK Sebagai Kebutuhan Dunia Kerja. Jurnal Bangunan. 23(1).

Pasaribu, B. 2016. Dibutuhkan 750.000 Tenaga Kerja Konstruksi Bersertifikat. (online), http://www.medanbisnisdaily.com., diakses 10 November 2020.

Saputri, O.D. dan Rejekiningsih, T.W. 2011. Analisis Penyerapan Tenaga Kerja Di Kota Salatiga. (Online). http.//www.eprints.undip.ac.id., diakses 12 November 2020.

Simanjuntak, P.J. 1998. Pengantar Ekonomi Sumber Daya Manusia. Jakarta: Fakultas Ekonomi Universitas Indonesia.

Taufik, A.I. 2012. Pembaharuan Regulasi Jasa Konstruksi dalam Upaya Mewujudkan Struktur Usaha yang Kokoh, Andal, Berdaya Saing Tinggi dan Pekerjaan Konstruksi yang Berkualitas. Jurnal Rechts Vinding Media Pembinaan Hukum Nasional, 1(2): 215-235.

Undang-Undang Nomor 18 Tahun 1999 tentang Jasa Konstruksi (UUJK). 
Jurnal Rekayasa Tenik Sipil Universitas Madura Vol. 5 No. 2 Desember 2020 ISSN 2527-5542

Halaman Ini Sengaja Dikosongkan 


\title{
EVALUASI TARIF ANGKUTAN UMUM LYN N BERDASARKAN BIAYA OPERASIONAL KENDARAAN, ABILITY TO PAY, DAN WILLINGNESS TO PAY (Studi kasus: Angkot Lyn N, Rute Terminal Bratang - JMP, Kota Surabaya) Abraham Kambuaya ${ }^{1}$, Theresia $M_{C A}^{2}$ \\ 1,2 Jurusan Teknik Sipil, Fakultas Teknik Sipil dan Perencanaan, Institut Teknologi Adhi Tama Surabaya Email : longteyes@gmail.com
}

\begin{abstract}
ABSTRAK: Terminal Bratang - JMP adalah lokasi yang terletak di kota Surabaya, dimana lokasi tersebut dapat digunakan untuk melakukan penelitian, sehingga penentuan tarif sendiri harus dilihat dari sisi operator dan penumpang agar memuaskan keduanya. Diketahui bahwa tarif yang berlaku dilapangan berbeda dengan tarif menurut PERWALI Surabaya Nomor 76 Tahun 2014. Dari penelitian ini bertujuan untuk mengevaluasi tarif bererdasarkan Biaya Operasional Kendaraan (BOK), Ability To Pay (ATP), dan Willingness To Pay (WTP) terhadap tarif yang berlaku dan mengetahui karakteristik penumpang. Pengumpulan data dilapangan yaitu wawancara dengan pemilik kendaraan untuk mengetahui biaya berdasarkan BOK dan penyebaran kuisioner kepada penumpang untuk mengetahui kemampuan, kemauan, dan karakteristik terhadap tarif yang berlaku. Hasil perhitungan berdasarkan BOK Rp 9.023,44 /pnp, berdasarkan pada hari kerja dan hari libur sebesar Rp 5.000 /pnp untuk umum dan pelajar/mahasiswa berdasarkan WTP tarif pada hari kerja sebesar Rp 5.906,664 /pnp untuk umum, sedangkan untuk pelajar/mahasiswa sebesar Rp 5.416,66 dan pada hari libur tarif sebesar Rp 5.736,664 untuk umum, sedangkan tarif untuk pelajar/mahasiswa sebesar Rp 5.000/pnp. Hasil perhitungan menunjukan bahwa tarif berdasarkan BOK dan WTP lebis besar dari tarif menurut PERWALI Rp 4.000 /pnp kategori umum dan tarif yang berlaku dilapangan $\mathrm{Rp} 5.000$ /pnp, maka pemerintah setempat harus mengevaluasi tarif BOK dan peningkatan fasilitas angkot lyn N dikota Surabaya.
\end{abstract}

Kata Kunci: Evaluasi, tarif Biaya Operasional, Kendaraan, Ability To Pay, Willingness To Pay

\section{LATAR BELAKANG}

Kota Surabaya memiliki perkembangan transpotasi sangat cepat, khususnya pada angkutan umum, sehingga diperlukan peraturan dan pengawasan yang maksimal agar dapat melayani pengguna jasa secara baik.

Untuk menentukan besaran tarif angkot diperlukan kebijakan dari pemerintah, hal ini sangat penting agar dapat memuaskan pengguna jasa dan penyedia jasa. Angkutan kota di Surabaya banyak dijumpai karena sangat ekonomis dan memiliki rute yang dilalui cukup banyak mencapai 57 rute, sehingga untuk angkot lyn $\mathrm{N}$ pada rute Terminal Bratang JMP sendiri memiliki jarak $12 \mathrm{~km}$ dengan waktu tempuh 40 50 menit. Rute tersebut melayani daerah yang melewati tengah kota yaitu pada kawasan kampus, rumas sakit, tempat perbelanjaan, stasiun, dan lain-lain.

Studi terdahulu mengenai tarif angkutan sudah dilakukan oleh Pandia, IJ dan Simamora RM (2014), dimana penelitian ini menunjukkan bahwa dari hasil perhitungan BOK pengusaha angkutan umum mendapatkan keuntungan dimana tarif yang berlaku saat ini wajar untuk menutupi Biaya Operasional Kendaraan. Studi terdahulu mengenai Ability To Pay dan Willingness To Pay juga sudah dilakukan oleh Lestari (2016). Berdasarkan hasil penelitian dilapangan dapat diketahui bahwa mayoritas penumpang BST adalah berjenis kelamin perempuan, jenis pekerjaan terbanyak yaitu pelajar, dominan tujuan perjalanan untuk keperluan bisnis, pendapatan terbanyak berkisar pada Rp 900.001,00 - Rp 1.009.050,00 dan penilaian pelayanan BST cukup memuaskan. Dari hasil perhitungan ATP sebsar Rp 2.000 /pnp untuk pelajar dan untuk umum sebesar Rp 3.670 pnp. Hasil perhitungan WTP untuk pelajar sebesar Rp 1.555 dan untuk umum sebesar Rp 3.458. Tarif yang berlaku saat ini lebih besar dari tarif berdasarkan perhitungan ATP dan WTP, sehingga dari hasil diatas maka perlu ada kajian ulang penerapan tarif di lapangan agar sesuai dengan kemampuan dan kemauan para penggunanya.
Penetapkan tarif angkot menurut PERWALI sebesar Rp 4000 /pnp, bagi pelajar tarif angkot memiliki potongan 50\% atau Rp 2.000 dengan jarak tempuh $15 \mathrm{~km}$, selebihnya penambahan Rp 200/pnp per km. Tetapi kenyataan dilapangan tidak sesuai dengan peraturan Walikota Surabaya tahun 2014, dimana tarif angkot naik menjadi Rp 5000 /pnp dan khusus buat pelajar tarifnya naik sebesar Rp 3000 /pnp. Melihat tarif yang berlaku dilapangan dapat diketahui bahwa kondisi ekonomi masyarakat khusus penyedia jasa semakin naik dan banyak penilaian angkutan umum (angkot) membuat masyarakat memiliki pilihan terhadap angkutan online dan kendaraan pribadi sehingga mempengaruhi Biaya Operasional Kendaraan serta kemampuan dan kemauan terhadap pengguna angkot. Dari permasalahan tersebut perlu melakukan penelitian mengenai Biaya Operasional Kendaraan (BOK), kemampuan (Ability To Pay) dan kemauan (Willngeness To Pay) terhadap tarif yang berlaku menurut PERWALI dan tarif yang berlaku saat ini untuk mengetahui secara detail tarif atau biaya apa saja yang dikeluarkan bagi pengguna angkot lyn $\mathrm{N}$, trayek Bratang - JMP berdasarkan BOK dan daya beli penumpang.

\section{METODE PENELITIAN}

\section{Survei Pendahuluan}

Survey pendahuluan merupakan tahapan awal penelitian untuk secara langsung mengetahui keadaan dilapangan pada angkot lyn N trayek Bratang - JMP. Survey pendahuluan dilakukan pada :

Hari/Tanggal

Jam

Jumblah surveyor

: Sabtu, 29 Februari 2020

: 09.00 - 11.00 WIB

Survey pendahuluan dapat dibagi menjadi beberapa bagian, yaitu:

1. Penentuan lokasi survey dan menentukan serta mengenal trayek yang telah dilalui oleh angkot.

2. Penentuan waktu survey dilakukan pada saat jam sibuk dan jam tidak sibuk. 
3. Penentuan jumlah surveyor dimana agar dapat membantu proses jalannya penganbilan data yang efissien dan efektif.

4. Pengecekan kembali form survey.

\section{Pengumpulan Data}

Pada tahapan ini pengumpulan data secara langsung dapat diperoleh dari hasil survey dilapangan. Pengumpulan data dibagi menjadi dua bagian, yaitu:

1. Data Primer

Adapun data primer, yaitu :

- Tujuan perjalanan

- Jumblah penumpang

- Biaya transportasi penumpang

- Penlilaian terhadap pelayanan angkot

- Penilaian terhadap tarif yang sesuai

- Frekuensi pengguna angkor

- Penghasilan penumpang per bulan

2. Data Sekunder

Adapun data sekunder, yaitu:

- Biaya Langsung

- Biaya Tidak Langsung

\section{Analisis Dan Pembahasan}

Analisis dan pembahsaan adalah hasil dari data survey yang didapat dari sopir dan penumpang angkutan umum. Data survey berdasrkan dari hasil:

1. Wawancara, yaitu data dari hasil survey Biaya Operasional Kendaraan (BOK) angkot lyn N, trayek Terminal Bratang - JMP.

2. Kuisioner, yaitu hasil dari responden untuk menganalisis besarnya nilai ATP dan WTP penumpang angkot lyn N, trayek Bratang - JMP.

\section{Lokasi Survei}

- Lokasi survey : Trayek Terminal Bratang - JMP

- Alamat

: Jl. Nginden Kota II, No.1 dan Jl.

Rajawali, Kec. Krembangan-Kota Surabaya.

- Jarak tempuh : $12 \mathrm{~km}$

Survey awal dilakuakan secara kecil pada tanggal 29 Februari 2020 seperti bawah ini,

- No. polisi kendaraan

$$
\text { : L } 1279 \text { UD }
$$

- Merek

Mitsubishi

- Tipe / model

: Colt T120 SS

- Tipe mesin

: $1300 \mathrm{CC}$

- Jenis bahan bakar : Bensin atau Premium

- Transmisi : Manual

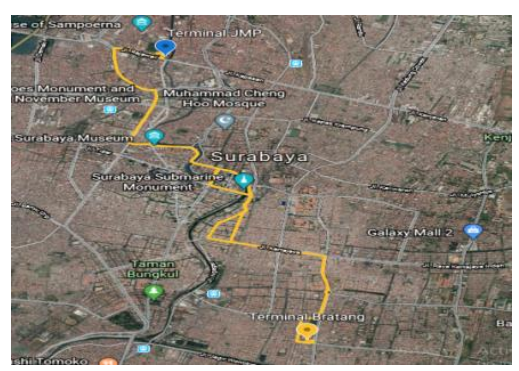

Gambar 1. Lokasi Survey, Terminal Bratang - JMP

\section{ANALISIS DAN PEMBAHASAN}

\section{Pelaksanaan Survei}

Survei untuk BOK dilaksanakan pada tanggal 29 Februari 2020, survei dilakukan jam 09.00 - 11.00 WIB. Sedangkan untuk survei ATP dan WTP dilaksanakan tiga hari dimana pada hari kerja dan hari libur. Survei pada hari kerja dilaksanakan dua hari yaitu tanggal 03 Agustus 2020 dan 04 Agustus 2020 yaitu survei pada jam sibuk 08.00 - 10.30 dan pada jam tidak sibuk 11.30 - 14.00 WIB. Survei pada hari libur dilaksanakan satu hari yaitu pada 09 Agustus 2020 dengan jam yang sama pada hari kerja, dimana survei pada jam sibuk 08.00 - 10.30 WIB dan jam tidak sibuk 11.30 14.00 WIB. Survei dilaksanakan dari terminal Bratang terminal JMP -Terminal Bratang dengan tenaga bantu survei dilapangan 2 orang.

\section{Pengambilan Data}

Pengambilan data atau sampel kepada pengguna jasa angkot lyn $\mathrm{N}$ dimana untuk mengetahui penilaian penumpang angkutan umum (angkot) terhadap tarif yang berlaku, ditinjau dari Biaya Operasional Kendaraan (BOK), Abality To Pay (kemampuan membayar) dan Willingness To Pay (kemauan membayar). Hasil survei data populasi pengguna jasa angkot lyn $\mathrm{N}$ terdapat pada Tabel 1:

Tabel 1. Populasi Pengguna Angkot Lyn N

\begin{tabular}{|l|c|c|c|}
\hline Jenis Hari & $\begin{array}{c}\text { Rata-rata } \\
\text { Penumpang/ang } \\
\text { kot/hari }\end{array}$ & $\begin{array}{c}\text { Jumlah } \\
\text { angkot }\end{array}$ & Populasi/hari \\
\hline Hari kerja & 10 & 2 & 20 \\
\hline Hari libur & 7 & 2 & 14 \\
\hline
\end{tabular}

Perhitungan besarnya sampel menggunakan rumus Slovin:

1. Hari kerja

$$
\mathrm{n}=\frac{\mathrm{N}}{1+\mathrm{Ne}^{2}}=\frac{20}{1+\left(20 \times 0,04^{2}\right)}=19,37984496
$$

2. Hari libur

$$
\mathrm{n}=\frac{\mathrm{N}}{1+\mathrm{Ne}^{2}}=\frac{14}{1+\left(14 \times 0,04^{2}\right)}=13,69327074
$$

Analisis Tarif Berdasarkan Biaya Operasional Kendaraan

1. Karakterisitik Kendaraan
a. Type
b. Jenis Pelayanan
: Mitsubishi Colt T120 SS
c. Kapasitas/Daya Angkut : 12 Orang
d. Load Factor : $70 \%$
e. Kapasitas oli mesin :4 Liter
f. Kapasitas BBM
: 42 Liter

2. Produksi Per Kendaraan
a. Km Tempuh/Rit (12 km-tempuh/trip)
$=24 \mathrm{~km} / \mathrm{rit}$
b. Frekuensi/Hari (4 trip/hari)
$=2$ rit
c. Km-Tempuh/Hari (a x b) $(\mathrm{KMH})$
$=48 \mathrm{~km} /$ hari
d. Hari Operasi/Bulan
$=24$ hari
e. Km Tempuh/Bulan (c x d) (KMB)
$=1.152$
$\mathrm{km} / \mathrm{bln}$
f. Frekuensi/Bulan (b x d)
$=48$ Rit
g. Km-Tempuh /Tahun (e x12Bln) (KMT)
$=13.824$
h. Penumpang /Rit
$\mathrm{km} / \mathrm{tahun}$
i. Penumpang /Hari (h $\mathrm{x}$ b) $(\mathrm{PH})$
j. Penumpang /Bulan (h x f) (PB)
$=10 \mathrm{pnp} / \mathrm{rit}$
$=20 \mathrm{pnp} / \mathrm{hr}$
$=480$
pnp/bulan 
k. Penumpang /Tahun (j x 12Bln) $(\mathrm{PT}) \quad=5.769$ pnp/thn

3. Biaya Per Kendaraan Mpu-Km

a. Biaya Langsung

- Biaya Penyusutan

- Harga Kendaraan (HK) = Rp 130.000.000

- Masa Penyusutan (MS) = 5 Tahun

- Nilai Residu (20\% dari HK) $(0,2 \times H K)$ $=\mathrm{Rp} 26.000 .000$

- Penyusutan Per Pnp $=\frac{130.000 .000-26.000 .000}{13.824 \times 5}$ $=\mathrm{Rp} 1504,63$ /Angkot-Km

- Biaya Awak Angkot

- Jumlah Awak

- Sopir = 1 Orang

- $\quad$ Kondektur $=0$ Orang Jumlah = 1 Orang

- Biaya Awak Angkot/Hari

- Pendapatan = Rp 100.000

- Tunjangan Kerja (makan, rokok, dll) $=\mathrm{Rp} 30.000$ Jumlah = Rp 130.000

- Biaya Awak Angkot/Bulan

- Pendapatan (100.000 x 24hari) $=\operatorname{Rp} 2.400 .000$

- Tunjangan kerja (30.000 x 24hari) $=\mathrm{Rp} 720.000$ Jumlah = Rp 3.120.000

- Biaya Awak Angkot/Tahun

- Pendapatan $1 \times 100.000 \times 24$ hari x 12 bulan $=\operatorname{Rp} 28.800 .000$

- Tunjangan kerja $1 \times 30.000 \times 24$ hari x 12 bulan $=\mathrm{Rp} 8.640 .000$

- Tunjangan sosial (THR) $=\mathrm{Rp} 0$ Jumlah = Rp 37.440.000

- Biaya Gaji /Pendapatan Pnp Biaya Awak Angkot /thn $=\frac{37.440 .000}{13.824}=\operatorname{Rp} 2.708,33$ /Angkot-Km

- Biaya BBM

- Pemakaian BBM = 10 Lt/Hari

- Harga BBM (premium) = Rp 6.550

- Pemakaian BBM /Rit (24/10Lt) = 2,40 Liter

- Biaya BBM /Angkot /Hari (10lt x 6.550) = Rp 65.500

- Biaya BBM /Km $\frac{\text { Harga BBM }}{\mathrm{KMH}}=\frac{65.500}{48}=\mathrm{Rp} 1364,58 /$ Angkot $-\mathrm{Km}$

- Ban

- Jumlah Ban = 4 Buah

- Daya Tahan Ban $\quad=20.000 \mathrm{Km}$

- Harga Ban = Rp 380.000

- Biaya Ban /Angkot $(1 \times 3)=$ Rp 1.520.000

- Biaya Ban / Km

$\frac{\text { Biaya Ban }}{\text { Daya Tahan Ban }}=\frac{1.520 .000}{20.000}=\mathrm{Rp} 76,00 /$ Angkot-Km

- Servis Kecil

- Servis kecil dilakukan setiap $\quad=5.000 \mathrm{Km}$
- Biaya Bahan :

Oli Mesin (4lt x Rp 50.000/lt) = Rp 200.000 Gemuk $(0,5 \mathrm{~kg} \times \mathrm{Rp} 9.500 / \mathrm{lt})=\mathrm{Rp} 2.000$

Minyak Transmisi (01t x Rp 9.500/lt $=\mathrm{Rp} 0$

Kanvas rem (2 ban $x$ Rp 115.000) $=R p 310.000$

- Ongkos service = Rp 145.000 Jumlah $=$ Rp 657.000

- Biaya service kecil /Pnp

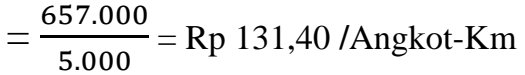

- Servis Besar

- Service besar dilakukan setiap $=10.000 \mathrm{Km}$

- Biaya Bahan:

Oli Mesin (4lt x Rp 50.000) = Rp 200.000

Oli Gardan (1lt x Rp 40.000) = Rp 40.000

Oli Persneling (1lt x Rp 80.000) $=\mathrm{Rp} 80.000$

Oli Filter (1bh $x$ Rp 30.000) = Rp 30.000

Gemuk $(0,5 \mathrm{~kg} \times \mathrm{Rp} 9.500 / \mathrm{lt}) \quad=\mathrm{Rp} 2.000$

Minyak rem 0,5lt (1 x 40.000/bh) $=\operatorname{Rp} 40.000$

- Ongkos service $=\mathrm{Rp} 500.000$ Jumlah $=\operatorname{Rp~} 892.000$

- Biaya Service Besar /Km Jum. Biaya Service Besar $=\frac{892.000}{10.000}=\mathrm{Rp} \mathrm{89,20/ \text {Angkot-Km }}$

- Biaya General Overhaul

- General overhaul dilakukan setiap $=300.000 \mathrm{~km}$

- Biaya overhaul:

- Suku cadang (5\% dari harga kend), $0,05 \times$ harga kend $=\operatorname{Rp} 2.000 .000$

- Perbaikan Body $=$ Rp 4.000 .000

- Ongkos service $=\mathrm{Rp} 700.000$

- Jumlah = Rp 6.700.000

- Biaya overhaul /Km $=\frac{\text { Biaya overhaul }}{\text { Jarak setiap overhaul }}$ $=\frac{6.700 .000}{300.000}=\mathrm{Rp} 22,33 /$ Angkot $-\mathrm{Km}$

- Penambahan Oli Mesin

- Penambahan oli mesin /hari $\quad=0,25 \mathrm{Lt}$

- $\mathrm{Km}$ tempuh /hari (KMH) $=48 \mathrm{Km}$

- Harga Oli /Lt = Rp 50.000

- Biaya Penambahan Oli Mesin /Pnp $=\frac{\text { Penambahan Oli } x \text { Harga Oli }}{\text { KMH }}=\frac{0,25 \times 50.000}{48}$ $=\operatorname{Rp} 260,42 /$ Angkot-Km

- Cuci Angkot

- Biaya cuci angkot /bulan = Rp 20.000

- Biaya Cuci Angkot /Km $=\frac{20.000}{1.152}=\mathrm{Rp} 17,36 /$ Angkot $-\mathrm{Km}$

- Retribusi Terminal

- Retribusi Terminal /Hari = Rp 2.000

- Biaya Retribusi Terminal/Pnp: $=\frac{2.000}{48}=\mathrm{Rp} 41,67 /$ Angkot $-\mathrm{Km}$

- STNK

- Biaya STNK /Angkot $/$ Thn $=$ Rp 210.000

- Biaya STNK /Km

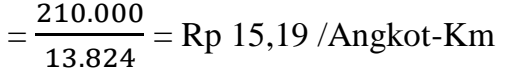


- KIR

- Frekuensi KIR/Thn $\quad=2$ Kali

- Biaya setiap kali KIR $\quad=$ Rp 90.000

- Biaya KIR/Thn = Rp180.000

- Biaya KIR /Pnp Angkot $=\frac{180.000}{13,824}=\operatorname{Rp~13,02/Angkot-Km}$

- Asuransi

- Asuransi Kend/Thn = Rp 120.000

- Asuransi Awak Angkot/Thn = Rp 0 Jumlah = Rp 120.000

- Biaya Asuransi /Pnp /Angkot

$$
\frac{\text { Asuransi Kend }}{\text { KMT }}=\frac{120.000}{13.824}=\operatorname{Rp~8,68}
$$

b. Biaya Tidak Langsung

- Biaya Pengelolaan /Tahun

Biaya izin Trayek = Rp 50.000

Biaya izin Usaha $\quad=\operatorname{Rp} 25.000$

Biaya lain-lain (Diluar unsur diatas) $=\mathrm{Rp} 500.000$

Sub Total $(b)=\operatorname{Rp} 575.000$

- Total Biaya Tidak Langsung /thn (a) + (b) $=\operatorname{Rp} 575.000$

- Total biaya tidak langsung /Angkot/Thn $=\frac{575.000}{1}=\operatorname{Rp} 575.000 /$ Angkot $/$ Thn

- Biaya tidak langsung /angkot-km $=\frac{575.000}{13.824}=\operatorname{Rp} 41,59$ /Angkot-Km

c. Rekapitulasi Biaya Langsung dan Biaya Tidak Langsung /Angkot-Km

Tabel 2. Rekapitulasi Biaya Langsung dan Biaya Tidak

\begin{tabular}{|c|c|c|}
\hline \\
\hline No & A. Biaya Langsung & /Angkot-Km \\
\hline 1 & Penyusutan & Rp 1504,63 \\
\hline 2 & Gaji dan Tunjangan & Rp 2708,33 \\
\hline 3 & Bbm & Rp 1364,58 \\
\hline 4 & Ban & $\operatorname{Rp} 76,00$ \\
\hline 5 & Service kecil & $\mathrm{Rp} 131,40$ \\
\hline 6 & Service besar & $\mathrm{Rp} 89,20$ \\
\hline 7 & General overhaul & Rp 22,33 \\
\hline 8 & $\begin{array}{c}\text { Penambahan oli } \\
\text { mesin }\end{array}$ & RP 260,42 \\
\hline 9 & Cuci kend & RP 17,36 \\
\hline 10 & Retribusi terminal & $\operatorname{Rp} 41,67$ \\
\hline 11 & STNK & $\operatorname{Rp} 15,19$ \\
\hline 12 & KIR & Rp 13,02 \\
\hline 13 & Asuransi & Rp 8,68 \\
\hline \multicolumn{2}{|r|}{ Jumlah } & $\begin{array}{c}\text { Rp 6.267,82 /Ankot- } \\
\text { km }\end{array}$ \\
\hline B & $\begin{array}{c}\text { Biaya Tidak } \\
\text { Langsung }\end{array}$ & Rp 41,59 /Angkot-km \\
\hline
\end{tabular}
Langsung

- Biaya Pokok /Angkot-km:

Biaya Langsung = Rp 6.267,82 /Angkot$\mathrm{km}$

Biaya Tidak Langsung $=\mathrm{Rp} 41,59$ /Angkot-km Jumlah

$=\operatorname{Rp} 6.309,41$ /Angkot$\mathrm{km}$

- Biaya Pokok Per Pnp-Km

$$
=\frac{6.309,41}{12}=\operatorname{Rp} 525,78 / \mathrm{Pnp}-\mathrm{Km}
$$

Perhitungan faktor muat (load factor) eksisting sebesar 70\% (Peraturan Jendral Perhubungan Darat Tahun 2002), dimana menentukan biaya pokok pada load factor sebesar:

- Tarif Pokok

$$
=\frac{6.309,41}{70 \% \times 12}=\frac{6.309,41}{8,4}=\mathrm{Rp} 751,12 / \mathrm{Pnp} / \mathrm{Km}
$$

- Biaya per penumpang :

$$
\begin{aligned}
& =(751,12 \times 12)+10 \% \\
& =\operatorname{Rp} 9.023,44 / \text { Pnp-Km }
\end{aligned}
$$

Perhitungan Ability To Pay

1. ATP Hari Kerja

Tabel 3. Rakapitulasi ATP pada hari kerja

\begin{tabular}{|l|c|c|c|c|c|}
\hline Pekerjaan & $\begin{array}{c}\text { It } \\
(\mathbf{R p})\end{array}$ & $\begin{array}{c}\mathbf{P p} \\
(\boldsymbol{\%})\end{array}$ & $\begin{array}{c}\mathbf{P t} \\
(\boldsymbol{\%})\end{array}$ & $\mathbf{T t}$ & $\begin{array}{c}\text { ATP } \\
(\mathbf{R p})\end{array}$ \\
\hline $\begin{array}{l}\text { Pelajar/ } \\
\text { mahasiswa }\end{array}$ & 6.200 .000 & 9,83 & 28,68 & 35 & 5.000 \\
\hline $\begin{array}{l}\text { Pegawai } \\
\text { swasta }\end{array}$ & 8.100 .000 & 10,37 & 62,5 & $\begin{array}{c}10 \\
5\end{array}$ & 5.000 \\
\hline IRT & 8.700 .000 & 6,78 & 43,22 & 45 & 5.666 \\
\hline Wiraswasta & 9.000 .000 & 8,33 & 60 & 90 & 5.000 \\
\hline Lainnya & 3.500 .000 & 10,71 & 26,66 & 20 & 5.000 \\
\hline
\end{tabular}

$$
=\frac{9.000 .000 \times 10,71 \% \times 26,66 \%}{90}=\mathrm{Rp} 5.000 / \mathrm{pnp}
$$

2. ATP Hari Libur

Tabel 4. Rekapitulasi ATP hari libur

\begin{tabular}{|l|c|c|c|c|c|}
\hline Pekerjaan & $\begin{array}{c}\text { It } \\
(\mathbf{R p})\end{array}$ & $\begin{array}{c}\text { Pp } \\
(\%)\end{array}$ & $\begin{array}{c}\text { Pt } \\
(\mathbf{\%})\end{array}$ & $\mathbf{T t}$ & $\begin{array}{c}\text { ATP } \\
(\mathbf{R p})\end{array}$ \\
\hline $\begin{array}{l}\text { Pelajar/ } \\
\text { mahasiswa }\end{array}$ & 1.650 .000 & 10,90 & 19,44 & 7 & 5.000 \\
\hline $\begin{array}{l}\text { Pegawai } \\
\text { swasta }\end{array}$ & 4.840 .000 & 14,66 & 59,15 & 84 & 5.000 \\
\hline IRT & 5.000 .000 & 12,9 & 41,86 & 54 & 5.000 \\
\hline Wiraswasta & 7.800 .000 & 8,33 & 50,9 & 56 & 5.000 \\
\hline Lainnya & 4.500 .000 & 9,79 & 27,27 & 24 & 5.000 \\
\hline
\end{tabular}

\begin{tabular}{|c|c|c|c|c|c|}
\hline \multirow[t]{2}{*}{ Pekerjaan } & \multicolumn{4}{|c|}{$\begin{array}{l}\text { Tarif yang dibayar } \\
\text { (Rp) }\end{array}$} & \multirow[t]{2}{*}{$\%$} \\
\hline & 5.000 & 6.000 & 6.500 & 7.000 & \\
\hline $\begin{array}{l}\text { Pelajar/ } \\
\text { Mhswa }\end{array}$ & 4 & 1 & 1 & & 30 \\
\hline Peg. Swasta & 1 & 2 & & 1 & 20 \\
\hline IRT & 2 & 2 & 1 & & 25 \\
\hline Wiraswasta & & 2 & 1 & & 15 \\
\hline Lainnya & 1 & 1 & & & 10 \\
\hline Jumlah & 3 & 8 & 3 & 1 & 100 \\
\hline
\end{tabular}

Sumber: Hasil perhitungan

$$
=\frac{7.800 .000 \times 8,33 \% \times 50,9 \%}{56}=\mathrm{Rp} 5.000 / \mathrm{pnp}
$$

\section{Perhitungan Willingnes To Pay}

1. WTP Hari Kerja

Tabel 5. Jumlah responden berdasarkan kemauan membayar pada hari libur

a. WTP Jenis Pekerjaan

- Kategori pelajar/mahasiswa $=\frac{(4 \times \mathrm{Rp} \mathrm{5000})+(1 \times \mathrm{Rp} \mathrm{6000})+(1 \times \mathrm{Rp} \mathrm{6.500})}{6}$ 
$=\operatorname{Rp} 5.416,66 / \mathrm{pnp}$

- Kategori pegawai swasta

$=\frac{(1 \times \mathrm{Rp} \mathrm{5000})+(2 \times \mathrm{Rp} \mathrm{6000})+(1 \times \mathrm{Rp} \mathrm{7.000})}{4}$
$=\operatorname{Rp} 6.000 / \mathrm{pnp}$

- Kategori IRT (Ibu rumah tangga)

$=\frac{(2 \times \mathrm{Rp} \mathrm{5000})+(2 \times \mathrm{Rp} 6000)+(1 \times \mathrm{Rp} \mathrm{6.500})}{5}$

$=\operatorname{Rp} 5.700$

- Kategori wiraswasta

$=\frac{(2 \times \mathrm{Rp} \mathrm{6.000})+(1 \times \mathrm{Rp} \mathrm{6.500)}}{3}$

$=\operatorname{Rp} 6.166,66 / \mathrm{pnp}$

- Kategori lain-lain

$=\frac{(1 \times \mathrm{Rp} 6.000)+(1 \times \mathrm{Rp} 6.500)}{2}=\mathrm{Rp} 6.250 / \mathrm{pnp}$

b. WTP Total Pekerjaan

$=\frac{5.416,66+6.000+5.700+6.166,66+6.250}{5}$

$=\operatorname{Rp} 5906,664 / \mathrm{pnp}$

2. Hari Libur

Tabel 6. Jumlah responden berdasarkan kemauan membayar pada hari libur

\begin{tabular}{|c|c|c|c|c|c|}
\hline \multirow{2}{*}{ Pekerjaan } & \multicolumn{4}{|c|}{ Tarif yang dibayar } & \multirow{2}{*}{$\%$} \\
\cline { 2 - 5 } & 5.000 & 6.000 & 6.500 & 7.000 & \\
\hline $\begin{array}{c}\text { Pelajar/ } \\
\text { Mhswa }\end{array}$ & 2 & & & & 13 \\
\hline Peg. Swasta & & 2 & & 1 & 20 \\
\hline IRT & 2 & 2 & & & 34 \\
\hline Wiraswasta & & 2 & 1 & & 20 \\
\hline Lainnya & & 1 & 1 & & 13 \\
\hline Jumlah & 4 & 7 & 2 & 1 & 100 \\
\hline
\end{tabular}

Sumber: Hasil Perhitungan

a. WTP pekerjaan

- Kategori pelajar/mahasiswa $=\frac{(2 \times \mathrm{Rp} \mathrm{5.000)}}{2}=\operatorname{Rp} 5.000 / \mathrm{pnp}$

- Kategori pegawai swasta $=\frac{(2 \times \mathrm{Rp} \mathrm{5.000})+(1 \times \mathrm{Rp} \mathrm{7.000})}{3}=\operatorname{Rp} 5.666,66 / \mathrm{pnp}$

- Kategori IRT $=\frac{(2 \times \mathrm{Rp} \mathrm{5000})+(2 \times \mathrm{Rp} 6000)}{4}=\mathrm{Rp} 5.500 / \mathrm{pnp}$

- Kategori wiraswasta $=\frac{(2 \times \mathrm{Rp} 6.000)+(1 \times \mathrm{Rp} \mathrm{6.500)})}{3}=\operatorname{Rp} 6166,66 / \mathrm{pnp}$

- Kategori lain-lain

$$
=\frac{(1 \times \mathrm{Rp} 6.000)+(1 \times \mathrm{Rp} \mathrm{6.500})}{2}=\mathrm{Rp} 6.250 / \mathrm{pnp}
$$

b. WTP Kategori Umum

Rp 5.000 + Rp 5.666,66 + Rp 5.500 + Rp 6166,66 + Rp 6.250

$=\operatorname{Rp} 5.736,664 / \mathrm{pnp}$

Rekapitulasi Tarif Berdasarkan BOK, ATP dan WTP

Tabel 7. Rekapitulasi tarif BOK, ATP, danWTP

\begin{tabular}{|c|c|}
\hline Jenis Tarif & $\begin{array}{c}\text { Nilai Tarif } \\
(\mathrm{Rp} / \text { Pnp) }\end{array}$ \\
\hline
\end{tabular}

\begin{tabular}{|l|c|}
\hline $\begin{array}{l}\text { Berdasarkan } \\
\text { perhitungan } \\
\text { BOK }\end{array}$ & $9.023,44$ \\
\hline $\begin{array}{l}\text { Berdasarkan } \\
\text { WTP } \\
\text { (penumpang } \\
\text { umum dan } \\
\text { pelajar }\end{array}$ & $\begin{array}{r}\text { Hari kerja: umum }=5906,664 \\
\text { pelajar }=5.416,66\end{array}$ \\
\hline $\begin{array}{l}\text { Berdasarkan } \\
\text { ATP } \\
\text { (penumpang } \\
\text { umum dan } \\
\text { pelajar) }\end{array}$ & $\begin{array}{r}\text { Hari kerja: umum }=5.736,664 \\
\text { pelajar }=5.000\end{array}$ \\
\hline $\begin{array}{l}\text { Tarif } \\
\text { berdasarkan }\end{array}$ & $\begin{array}{r}\text { Hari libur: umum }=5.000 \\
\text { pelajar }=5.000\end{array}$ \\
$\begin{array}{l}\text { PERWALI } \\
\text { 2014 }\end{array}$ & Kategori : umum $=4.000$ \\
\hline $\begin{array}{l}\text { Tarif yang } \\
\text { berlaku saat ini }=2.000\end{array}$ & \\
\hline
\end{tabular}

Dari Tabel 7 dapat dilihat bahwa tarif berdasarkan BOK, sedangkan berdasarkan PERWALI tahun 2014 untuk kategori umum sebesar Rp 4.000 dan tarif pelajar potongan $50 \%$ atau Rp 2.000, tarif yang berlaku saat ini yaitu Rp 5.000 kategori umum sedangkan untuk pelajar tarif sebesar $\mathrm{Rp}$ 4.000. Dari hasil perhitungan BOK dapat dilihat bahwa lebih besar dari tarif yang berlaku dan tarif berdasarkan perhitungan ATP serta WTP. Hal ini karena biaya penyusutan, gaji/tunjangan, BBM sangat besar sehingga berpengaruh pada hasil perhitungan BOK. Dilihat pada hasil perhitungan ATP sama dengan tarif yang berlaku sebesar Rp 5.000/pnp dan lebih kecil dari kemauan (WTP) membayar, sedang untuk hasil perhitungan WTP lebih besar dari tarif yang berlaku dan hasil perhitungan ATP. Hal ini terjadi dikarenakan kemauan membayar penumpang lebih besar tetapi harus diimbangi dengan fasilitas angkot lyn N. Menenurut PERWALI tahun 2014 tentang perbedaan tarif berdasarkan penumpang umum dan pelajar karena dilihat dari sisi usia dan kemampuan ekonomi, dimana untuk penumpang umum dapat diketahui bahwa berkecukupan untuk membayar dari segi usia dan mampu membayar dari sisi ekonomi karena ada penghasilan, begitupun sebaliknya untuk pelajar dimana karena pelajar dilihat dari sisi ekonomi dan usia belum mampu membayar karena tidak ada penghasilan.

Karakteristik Penumpang

1. Hari Kerja

- Jenis Kelamin Tabel 8. Persentase jenis kelamin responden

\begin{tabular}{|c|c|c|}
\hline Jenis kelamin & Jumlah & \% \\
\hline Perempuan & 12 & 60 \\
\hline Laki-laki & 8 & 40 \\
\hline Total & 20 & 100 \\
\hline
\end{tabular}

Tabel 8 diatas menunjukan bahwa jumlah responden jenis kelamin pada hari kerja, yaitu terdapat 20 jenis kelamin dimana presentase sebesar $60 \%$ untuk penumpang dengan jenis kelamin wanita dan $40 \%$ penumpang dengan jenis kelamin pria. Dari hasil peresentase tersebut dilihat bahwa penumpang dengan jenis kelamin perempuan yang 
terbanyak, hal ini karena kebanyakan perempuan ada yang belanja dipasar, berjualan, dan bekerja.

- Pendapatan Penumpang

Pendapatan penumpang pada pengguna jasa angkot lyn $\mathrm{N}$ dapat mempengaruhi kemampuan membayar, jika penumpang tersebut memiliki pendapatan tinggi, maka kemampuan membayar juga tinggi dan begitupun sebaliknya.

Tabel 9 Persentase pendapatan penumpang pada hari kerja

\begin{tabular}{|c|c|c|}
\hline $\begin{array}{c}\text { Pendapatan } \\
(\mathbf{R p})\end{array}$ & Jumlah & \% \\
\hline $500.000-1.000 .000$ & 8 & 40 \\
\hline $1.500 .000-2.000 .000$ & 5 & 25 \\
\hline $2.000 .000-2.500 .000$ & 3 & 15 \\
\hline $2.500 .000-3.000 .000$ & 3 & 15 \\
\hline$>3.000 .000$ & 1 & 5 \\
\hline Total & 20 & 100 \\
\hline
\end{tabular}

Dilihat pada Tabel 9, pendapatan pengguna jasa angkot lyn $\mathrm{N}$ memiliki pendapatan rendah, dimana dari hasil presentase pendapatan penumpang terendah, yaitu $40 \%$ atau sebesar Rp 500.000 - Rp 1.000.000. Di karenakan tidak membeli kendaraan pribadi.

- Responden Berdasarkan Tujuan Perjalanan dan Jenis Pekerjaan Pada Hari Kerja.

Tabel 10 Jumlah responden berdasarkan maksud perjalanan dan pekerjaan pada hari kerja

\begin{tabular}{|c|c|c|c|c|c|c|}
\hline \multirow[b]{2}{*}{ Pekerjaan } & \multicolumn{6}{|c|}{ Maksud Perjalanan } \\
\hline & $\frac{B}{D}$ व & 光 & $\bar{D}$ & 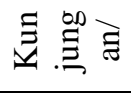 & $\frac{\mathscr{v}}{\mathscr{Q}}$ & ] \\
\hline Pelajar/Msw & & 4 & 1 & & 1 & \\
\hline Peg. Swasta & 3 & & & & & 1 \\
\hline IRT & & & 5 & & & \\
\hline Wiraswasta & 2 & & & 1 & & \\
\hline Lainnya & 1 & & & 1 & & \\
\hline$\%$ & 30 & 20 & 30 & 10 & 5 & 5 \\
\hline
\end{tabular}

Dari Tabel 10 dapat dilihat bahwa berdasarkan maksud perjalanan dan perkerjaan pelajar/mahasiswa dan IRT yang terbanyak dalam maksud perjalanan. Hal ini karena pelajar/mahasiswa memilih transportasi angkot lyn $\mathrm{N}$ untuk tujuan ke kampus.

Tabel 11 Jumlah responden berdasarkan kemauan membayar tarif dan jenis pekerjaan pada hari kerja

\begin{tabular}{|c|c|c|c|c|c|}
\hline \multirow[t]{2}{*}{ Pekerjaan } & \multicolumn{4}{|c|}{$\begin{array}{c}\text { Tarif yang dibayar } \\
\text { (Rp) }\end{array}$} & \multirow[t]{2}{*}{$\%$} \\
\hline & 5.000 & 6.000 & 6.500 & 7.000 & \\
\hline $\begin{array}{l}\text { Pelajar/ } \\
\text { Mhswa }\end{array}$ & 4 & 1 & 1 & & 30 \\
\hline Peg. Swasta & 1 & 2 & & 1 & 20 \\
\hline IRT & 2 & 2 & 1 & & 25 \\
\hline Wiraswasta & & 2 & 1 & & 15 \\
\hline Lainnya & 1 & 1 & & & 10 \\
\hline Jumlah & 3 & 8 & 3 & 1 & 100 \\
\hline
\end{tabular}

Pada Tabel 11 dilihat bahwa dari jenis pekerjaan, keinginan membayar dominan $\mathrm{Rp} 6.000$ dan yang terbanyak melakukan tujuan perjalanan adalah perlajar/mahasiswa karena jalur angkutan tersebut melalui kampus.

2. Hari Libur

- Jenis Kelamin

Tabel 12 Persentase jenis kelamin responden pada hari libur

\begin{tabular}{|c|c|c|}
\hline Jenis kelamin & Jumlah & \% \\
\hline Perempuan & 8 & 57 \\
\hline Laki-laki & 6 & 43 \\
\hline Total & 14 & 100 \\
\hline
\end{tabular}

Berdasarkan Tabel 12, hasil peresentase tersebut dilihat bahwa penumpang dengan jenis kelamin perempuan yang terbanyak, hal ini karena kebanyakan perempuan ada yang melakukan aktivitas bertujuan belanja dipasar, berjualan, dan bekerja.

- Pendapatan Penumpang

Pendapatan penumpang pada pengguna jasa angkot lyn $\mathrm{N}$ dapat mempengaruhi kemampuan membayar, jika penumpang tersebut memiliki pendapatan tinggi, maka kemampuan membayar juga tinggi. Begitupun sebaliknya, jika pendapatan rendah maka kemampuan membayar pun rendah.

Tabel 13 Persentase pendapatan penumpang pada hari libur

\begin{tabular}{|c|c|c|}
\hline $\begin{array}{c}\text { Pendapatan } \\
(\mathbf{R p})\end{array}$ & Jumlah & \% \\
\hline $500.000-1.000 .000$ & 4 & 29 \\
\hline $1.500 .000-2.000 .000$ & 5 & 36 \\
\hline $2.000 .000-2.500 .000$ & 2 & 14 \\
\hline $2.500 .000-3.000 .000$ & 3 & 21 \\
\hline$>3.000 .000$ & 0 & 0 \\
\hline Total & 14 & 100 \\
\hline
\end{tabular}

Dilihat pada Tabel 13, persentase pendapatan pengguna jasa angkot lyn $\mathrm{N}$ dapat ketahui memiliki pendapatan terbesar, yaitu Rp 1.500.000 - 2.000.000.

Tabel 14 Persentase responden berdasarkan maksud perjalanan dan pekerjaan pada hari libur

\begin{tabular}{|c|c|c|c|c|c|c|}
\hline \multirow[b]{2}{*}{ Pekerjaan } & \multicolumn{6}{|c|}{ Maksud Perjalanan } \\
\hline & 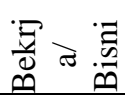 & $\frac{\breve{d}}{\omega} \frac{\pi}{0}=$ & $\bar{\otimes}$ & 壳 盯 & $\frac{y}{2}$ & ] \\
\hline $\begin{array}{l}\text { Pelajar/ } \\
\text { Mhswa }\end{array}$ & & & 1 & & 1 & \\
\hline Peg. Swasta & & & 1 & & 2 & \\
\hline IRT & & & 3 & & 1 & \\
\hline Wiraswasta & 2 & & & 1 & & \\
\hline Lainnya & & & 1 & & & 1 \\
\hline$\%$ & 14 & & 43 & 7 & 29 & 7 \\
\hline
\end{tabular}

Tabel 15 Jumlah responden berdasarkan kemauan membayar tarif dan jenis pekerjaan pada hari libur

\begin{tabular}{|c|c|c|c|c|c|}
\hline \multirow{2}{*}{ Pekerjaan } & \multicolumn{4}{|c|}{ Tarif yang dibayar } & \multirow{2}{*}{$\%$} \\
\cline { 2 - 5 } & 5.000 & 6.000 & 6.500 & 7.000 & \\
\hline $\begin{array}{c}\text { Pelajar/ } \\
\text { Mhswa }\end{array}$ & 2 & & & & 13 \\
\hline $\begin{array}{c}\text { Peg. } \\
\text { Swasta }\end{array}$ & & 2 & & 1 & 20 \\
\hline
\end{tabular}




\begin{tabular}{|c|c|c|c|c|c|}
\hline \multicolumn{2}{|l|}{ Lanjutan Tabel 15} \\
\hline IRT & 2 & 2 & & & 34 \\
\hline Wiraswast & & 2 & 1 & & 20 \\
\hline Lainnya & & 1 & 1 & & 13 \\
\hline Jumlah & 4 & 7 & 2 & 1 & 100 \\
\hline
\end{tabular}

Pada Tabel 15 dilihat bahwa dari jenis pekerjaan, keinginan membayar pada hari libur dominan Rp 6.000.

Tabel 16 Persentase karakteristik berdasarkan usia responden pada hari kerja dan libur angkot lyn $\mathrm{N}$

\begin{tabular}{|c|c|c|}
\hline Usia & Orang & \% \\
\hline $20-26$ & 9 & 26 \\
\hline $27-35$ & 7 & 21 \\
\hline $35-48$ & 11 & 32 \\
\hline $48-54$ & 6 & 18 \\
\hline$>54$ & 1 & 3 \\
\hline Jumlah & 34 & 100 \\
\hline
\end{tabular}

Tabel 17 Persentase status perkawinan responden pada hari kerja dan libur angkot lyn $\mathrm{N}$

\begin{tabular}{|c|c|c|}
\hline Status perkawinan & Orang & \% \\
\hline Menikah & 23 & 68 \\
\hline Belum menikah & 11 & 32 \\
\hline Jumlah & 34 & 100 \\
\hline
\end{tabular}

Tabel 18 Persentase karakteristik jumlah tanggungan responden pada hari kerja dan libur angkot lyn $\mathrm{N}$

\begin{tabular}{|c|c|c|}
\hline Jumlah tanggungan & Orang & \% \\
\hline Tidak ada & 14 & 41 \\
\hline 1 & 3 & 9 \\
\hline 2 & 7 & 20 \\
\hline 3 & 6 & 18 \\
\hline$>3$ & 4 & 12 \\
\hline Jumlah & 34 & 100 \\
\hline
\end{tabular}

Tabel 19 Persentase penumpang terhadap kualitas pelayanan angkot lyn $\mathrm{N}$ pada hari kerja dan libur

\begin{tabular}{|c|c|c|c|c|c|}
\hline \multirow{3}{*}{$\begin{array}{c}\text { Kualitas } \\
\text { pelayanan }\end{array}$} & \multicolumn{5}{|c|}{ Penilaian Penumpang } \\
\hline & 已 & 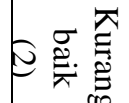 & \multicolumn{2}{|c|}{$\%$} & $\stackrel{-1}{\ddot{D}}$ \\
\hline & & & 1 & 2 & \\
\hline $\begin{array}{l}\text { Waktu tempuh } \\
\text { perjalanan }\end{array}$ & 15 & 19 & 44 & 56 & 34 \\
\hline $\begin{array}{l}\text { Kenyamanan dan } \\
\text { keselamatan }\end{array}$ & 28 & 6 & 82 & 18 & 34 \\
\hline Kebersihan & 12 & 22 & 35 & 65 & 34 \\
\hline Kelayakan & 24 & 8 & 75 & 25 & 34 \\
\hline \multicolumn{3}{|c|}{ Jumlah } & 100 & 100 & \\
\hline
\end{tabular}

Tabel 20 Persentase prioritas utama pelayanan angkot lyn $\mathrm{N}$ pada hari kerja dan libur.

\begin{tabular}{|c|c|c|}
\hline Prioritas utama & Orang & \% \\
\hline Waktu tempuh perjalanan & 7 & 21 \\
\hline Kenyamanan/keselamatan & 9 & 26 \\
\hline Kebersihan & 14 & 41 \\
\hline Kelayakan & 4 & 12 \\
\hline Jumlah & 34 & 100 \\
\hline
\end{tabular}

Tabel 20 dapat dilihat bahwa penumpang memiliki keinginan membayar lebih jika pelayanan pada angkot lyn $\mathrm{N}$ dapat ditingkatkan

\section{Pembahasan}

Dari tarif yang berlaku dan tarif yang dikeluarkan dari PERWALI tahun 2014 dapat dilihat bahwa berbeda dengan hasil perhitungan BOK, ATP, dan WTP. Hal ini dapat terjadi karena dari survei dilapangan, dimana dari perhitungan BOK mendapatkan tarif perpenumpang sangat besar yaitu $\mathrm{Rp}$ 9.023,44 /pnp dari tarif yang berlaku Rp 5.000 /pnp. Sedangkan tarif berdasarkan Peraturan Walikota Surabaya Nomor 76 Tahun 2014 ditentukan Tarif Batas Bawah (TBB) untuk mikrolet atau angkot sebesar Rp 4.000 /pnp jarak tempuh $15 \mathrm{~km}$ (lima belas kilo meter) dan Tarif Batas Atas (TBA) sebesar Rp 200 per km (200 rupiah per kilo meter). Maka dari hasil ini pemerintah kota Surabaya harus mengambil kebijakan atau memberikan solusi agar pengusaha penyedia jasa angkutan umum (angkot) dapat bertahan mencari penghasilan. Dari hasil survei dilapangan dapat diketahui bahwa banyak penumpang lebih memilih angkutan online atau kendaraan pribadi sehingga ketertarikan untuk menggunakan MPU atau angkot semakin berkurang dan hal ini mengakibatkan pendapatan penyedia jasapun angkutan semakin berkurang.

Tarif berdasarkan ATP dari hasil perhitungan:

1. Hari kerja

- Tarir penumpang umum : Rp 5.000/pnp

- Tarir pelajar

: Rp $5.000 / p n p$

2. Hari libur

- Tarif penumpang umum : Rp $5.000 / p n p$

- Tarif pelajar : Rp $5.000 / p n p$

Dari hasil tersebut dapat dilihat bahwa kemampuan membayar pada hari kerja dan libur sama dengan tarif yang berlaku saat ini.

Tarif berdasarkan WTP dari hasil perhitungan:

1. Hari kerja

- Tarif penumpang umum: Rp 5906,664/pnp

- Tarif pelajar

2. Hari libur

: Rp 5.416,66/pnp

- Tarif penumpang umum: Rp 5.736,66/pnp

- Tarif pelajar

: Rp $5.000 / p n p$

Dari hasil perhitungan WTP atau kemauan membayar dapat dilihat lebih besar dari hasil perhitungan ATP. Di mana hasil ini dapat lihat bahwa penghasilan penumpang besar dan mereka mau membayar lebih jika fasilitas, keamanan, kebersihan dan lain-lain harus ditingkat lagi. 


\section{KESIMPULAN DAN SARAN Kesimpulan}

Berdasarkan hasil perhitungan pada bab IV, hasil yang diperoleh sebagi berikut:

1. Tarif penumpang dari hasil perhitungan BOK kepada pengguna jasa angkutan umum (angkot) lyn $\mathrm{N}$ sebesar sebesar Rp 9.023,44 /pnp, sehingga dari perhitungan dapat dilihat bahwa tarif berdasarkan BOK lebih besar dari tarif yang berlaku, yaitu Rp 5.000 /pnp.

2. Tarif penumpang dari hasil perhitungan Ability To Pay (ATP) pada hari kerja dan hari libur sebesar Rp 5.000 /pnp. Dari hasil perhitungan, dapat dilihat besaran kemampuan membayar sama dengan tarif yang berlaku dilapangan yaitu Rp 5.000 /pnp, karena pendapatan penumpang rata-rata dengan kemampuan membayar. Sedangkan tarif yang berlaku pada hasil perhitungan Willingness To Pay (WTP) pada hari kerja sebesar Rp 5906,664/pnp untuk penumpang kategori umum, untuk kategori pelajar/mahasiswa sebesar Rp 5.416,66 /pnp dan WTP pada hari libur untuk kategori umum sebesar 5.736,664 /pnp dan tarif yang berlaku untuk pelajar sebesar Rp 5.000 /pnp, sedangkan tarif yang berlaku dilapangan sebesar Rp 5.000 /pnp. Dari hasil tersebut dapat dilihat bahwa kemauan membayar lebih besar dari tarif yang berlaku, sehingga dapat diketahui bahwa penumpang memiliki kemauan membayar lebih besar karena harus diimbangi dengan fasilitas angkot lyn N.

3. a. Persentase karakteristik responden berdasarkan usia pada hari kerja dan hari libur yaitu dominan pada usia 35 - 48 sebesar $32 \%$ karena diera modern seperti saat ini lebih dominan pengguna angkot rata-rata umur diatas 28 tahun.

b. Persentase jumlah responden berdasarkan jenis kelamin dominan jenis kelamin perempuan, yaitu pada hari kerja jenis kelamin perempuan berjumlah $60 \%$ dan pada hari libur berjumlah $57 \%$, hal ini terjadi kebanyakan perempuan ada yang melakukan aktivitas bertujuan belanja dipasar, berjualan, bekerja dan rekreasi.

c. Persentase responden berdasarkan status perkawinan pada hari kerja da hari libur yaitu dominan sudah menikah berjumlah $68 \%$.

d. Persentase responden berdasarkan jumlah tanggungan pada hari kerja dan libur dominan tidak ada tanggungan berjumlah $41 \%$.

e. Persentase rata-rata pendapatan responden per bulan pada hari kerja yaitu dominan $40 \%$ dengan pendapatan Rp 500.000 - Rp 1.000.000 dan pada hari libur berjumlah $36 \%$ dengan pendapatan Rp 1.500.000 - Rp 2.000.000.

f. Persentase jenis pekerjaan responden pada hari kerja yaitu dominan mahasiswa berjumlah $30 \%$ dan persentase pada hari libur yaitu dominan IRT berjumlah $29 \%$

g. Persentase responden berdasarkan tujuan perjalanan pada hari kerja yaitu dominan bekerja/bisnis berjumlah 30\% dan pada hari libur berjumlah $43 \%$ dengan tujuan perjalanan yaitu belanja.

h. Persentase responden berdasarkan penilaian kualitas pelayanan angkot lyn $\mathrm{N}$ pada hari kerja dan libur yaitu waktu tempuh perjalanan sebesar $19 \%$ kurang baik, keamanan sebesar $28 \%$ baik, kebersihan sebesar $22 \%$ kurang baik, dan kelayakan $24 \%$ baik.

i. Persentase berdasarkan biaya perjalanan pada hari kerja yaitu dominan $40 \%$ yaitu kemauan membayar Rp 5.000 - Rp 6.000, pada hari libur dominan $50 \%$ yaitu kemauan membayar Rp 6.000.

\section{Saran}

1. Tarif pada hasil perhitungan BOK dan WTP lebih tinggi dari tarif yang berlaku sehingga perlu ada kebijakan yang diambil dari pemerintah Kota Surabaya untuk mengevaluasi tarif angkutan umum.

2. Peningkatan pelayanan angkot dalam hal ini kenyamanan, kebersihan, waktu tempuh perjalanan dan kelayakan angkot.

3. Adanya pembatasan kendaraan pribadi dan angkutan online agar kapasitas muat (load factor) semakin meningkat.

\section{DAFTAR PUSTAKA}

Abbas salim, 2008. Manajemen Transportasi, graha ilmu Yogyakarta.

Direktorat Jenderal Perhubungan Darat SK.687/AJ.206/DRJD/2002, Pedoman Teknis Penyelenggaraan Angkutan Umum Di Wilayah Perkotaan Dalam Trayek Tetap Dan Teratur, Direktorat Perhubungan Darat.

Indra Jaya Pandia, Rico Mark Simamora (2014). Evaluasi Tarif Bus Antar Kota Dalam Propinsi (AKDP) Berdasarkan Biaya Operasional Kendaraan Trayek Medan-Doloksanggul, Universitas Sumatera Utara.

Lestari (2016), Analisis Kelayakan Tarif Batik Solo Trans (BST) Ditinjau Dari Ability To Pay (ATP) Dan Willingness To Pay (WTP), Universitas Muhammadiyah Surakarta.

Muhammad Rahmad Permata (2012), Analisa Ability To Pay dan Willigness To Pay Pengguna Jasa Kereta Api Bandara Soekarno Hatta - Manggarai, Universitas Indonesia.

Pedoman Skripsi Terdahulu Jurusan Teknil Sipil Institut Teknologi Adhi Tama Suarabaya.

Peraturan Walikota (PERWALI) Surabaya Nomor 76 Tahun 2014.

Rahman (2012), Analisa Biaya Operasi Kendaraan (BOK) Angkutan Umum Antar Kota Dalam Propinsi Rute Palu - Poso, Universitas Tadulako Palu

Rustian Kamaludin (1987), Ekonomi Transportasi, Jakarta: Ghalia Indonesia.

Tamin, O.Z. (1997). Perencanaan dan Permodelan Transportasi Edisi 1. Bandung : Penerbit ITB Bandung.

Warpani. (1990). Tujuan dan Peranan Angkutan Kota. Konsep Pelayanan Angkutan Kota website : perencanaankota.blogspot.co.id/2013/10/konseppelayanan-angkutan-kota.html. 


\title{
KINERJA ANGKUTAN UMUM AG (ARJOSARI - GADANG) PADA MASA PANDEMI COVID-19 KOTA MALANG
}

\author{
Rifky Aldila Primasworo ${ }^{1}$ dan Andreas Joni ${ }^{2}$ \\ ${ }^{1}$ Teknik Sipil, Fakultas Teknik, Universitas Tribhuwana Tunggadewi, Malang \\ ${ }^{2}$ Teknik Sipil, Fakultas Teknik, Universitas Tribhuwana Tunggadewi, Malang \\ E-mail: Rifky.unitrimalang@gmail.com,andreasjoni96@gmail.com.
}

\begin{abstract}
ABSTRAK: Angkutan umum penumpang yang disebut juga sebagai angkutan kota adalah salah satu sarana transportasi yang digunakan untuk melayani aktifitas masyarakat di Kota Malang. Pada saat Pandemi, volume jumlah penumpang pengguna jasa angkotan umum penumpang semakin hari semakin berkurang, namun pada dasarnya angkutan umum penumpang masih dibutuhkan oleh masyarakat Kota Malang dalam melakukan aktifitas sehari hari. Dalam pelayanannya waktu tempuh angkutan umum penumpang jalur $\mathrm{AG} \pm 1$ jam dengan jarak tempuh $\pm 16 \mathrm{~km}$. Adapun Tujuan dari penelitian ini adalah untuk mengetahui tingkat pelayanan angkutan umum penumpang trayek AG (Terminal Arjosari-Gadang) selama masa pandemi covid-19. Metode analisis data yang dipergunkan dalam penelitian ini yaitu metode deskriptif dan kuantitatif. Survey yang dilakukan menggunakan survey statis,dinamis dan wawancara atau interview. Hasil penelitian didapatkan bahwa Parameter kinerja lalu lintas yang perlu ditingkatkan selama pandemi covid-19 meliputi frekuensi angkutan umum, jumlah kendaraan yang beroperasi, waktu pelayanan (awal dan akhir waktu pelayanan).
\end{abstract}

Kata Kunci : angkutan umum, kinerja, pandemi

\section{PENDAHULUAN}

Kota Malang merupakan kota terbesar kedua di Jawa Timur setelah Kota Surabaya dan merupakan salah satu kota yang memiliki posisi sangat strategi secara geografis, selain itu Kota Malang terkenal dengan semboyan Tri Bina Citra yaitu sebagai Kota Pendidikan, Kota Industri dan Kota Parawisata yang mencerminkan profil potensi ekonomi Kota Malang. Padatnya kegitan berbanding lurus dengan perkembangannya pergerakan masyarakat yang menuntut kebutuhan transportasi yang lebih berkembang. Perkembangan tersebut menghadapkan Kota Malang pada keseimbangan antara supply dan demand, meningkatkanya jumlah pengguna kendaraan pribadi akibat rendahnya tingkat pelayanan dan Kinerja Angkutan Umum.

Angkutan umum penumpang di Kota Malang yang disebut angkutan kota adalah salah satu sarana transportasi yang digunakan untuk melayani aktifitas masyarakat di Kota Malang. Meskipun saat ini volume jumlah penumpang pengguna jasa angkotan umum penumpang yang semakin hari semakin berkurang, namun angkotan umum penumpang masih dibutuhkan oleh masyarakat kota malang dalam melakukan aktifitas sehari hari.

Permasalahan yang terjadi adalah dari data di lapangan ternyata kondisi angkutan umum penumpang AG (terminal arjosari-Gadang/Hamid Rusdi) mulai mencemaskan karena kurangnya penumpang yang berminat menggunakan jasa angkutan umum penumpang AG. hal ini di karena adanya kendaraan online seperti Greb atau Gojek, dan masyarakat Kota Malang banyak yang mempuyai kendaraan pribadi (motor/ mobil). Sedangkan jumlah kendaraan yang beroperasi di trayek AG sangat besar, sehingga berpengaruh terhadap pendapatan angkutan umum penumpang $\mathrm{AG}$, waktu tempuh angkutan umum penumpang jalur $A G \pm 1$ jam dengan jarak tempuh $\pm 16 \mathrm{~km}$.

Tujuan dari penelitian ini adalah untuk mengetahui tingkat kinerja angkutan umum AG pada masa panemi di tahun 2020 dan memberikan solusinya dalam meningkatkan kinerja angkutan umum.

\section{METODE PENELITIAN}

A. Diagram alir Penelitian

Dapat dilihat pada Gambar 1

B. Lokasi dan Waktu Survey

Lokasi penelitian angkutan umum penumpang trayek AG (Terminal Arjosari-Terminal Hamid Rusdi/Gadang) Kota Malang dengan panjang rute adalah $\mathrm{AG} \pm 16 \mathrm{~km}$. Untuk lebih jelasnya dapat dilihat pada Gambar 2.

\section{METODE PENGUMPULAN DATA}

Pengambilan data diperoleh dari data primer yaitu data yang diproleh dengan cara pengamatan langsung dilapangan. Pengumpulan data dilakukan semala tiga (3) hari yaitu pada hari kerja dan hari libur dari pukul 07: 00-17:00, karena jam tersebut diasumsikan berlangsungnya kegiatan penduduk dan data sekunder. Untuk lebih jelasnya dapat dilihat pada Tabel 1.

Tabel 1 Kebutuhan Data Sekunder

\begin{tabular}{|l|l|l|}
\hline No & \multicolumn{1}{|c|}{ Kebuhan Data } & \multicolumn{1}{c|}{ Instansi } \\
\hline 1 & Jumlah armada trayek AG & Dinas perhubungan \\
\hline 2 & Rute angkutan trayek AG & Dinas perhubuangan \\
\hline 3 & Panjang rute trayek AG & Dinas perhubungan \\
\hline 4 & Jumlah rit trayek AG & Dinas perhubungan \\
\hline 5 & Jam operasi trayek AG & Perum angkutan \\
\hline
\end{tabular}

Metode pengumpulan data meliputi data primer yaitu survey statis adalah survey yang dilakukan pada titik tertentu dengan mengamiati dan mencatat informasi dari setiap angkutan umum trayek Terminal ArjosariGadang/terminat hamid rusdi, survey dinamis adalah dengan cara menaiki angkutan umum rute Terminal Arjosari - Gadang/terminal hamid rusdi. Survey dinamis ini untuk jumlah data naik dan data turun penumpang, waktu keberagkatan dari terminal keberangkatan dan waktu angkutan tiba di terminal tujuan dan wawancara. 

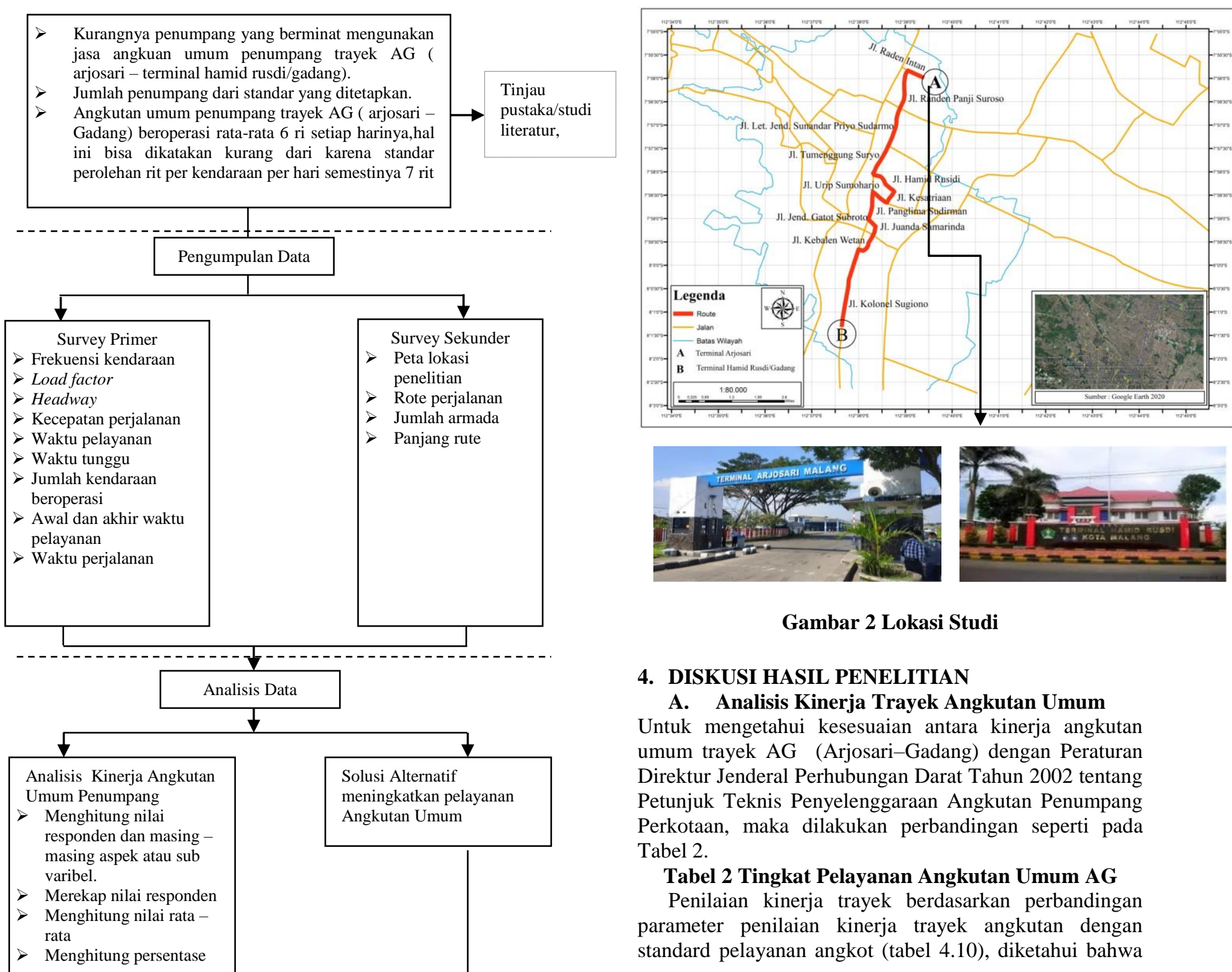

\section{Gambar 2 Lokasi Studi}

\section{DISKUSI HASIL PENELITIAN}

\section{A. Analisis Kinerja Trayek Angkutan Umum}

Untuk mengetahui kesesuaian antara kinerja angkutan umum trayek AG (Arjosari-Gadang) dengan Peraturan Direktur Jenderal Perhubungan Darat Tahun 2002 tentang Petunjuk Teknis Penyelenggaraan Angkutan Penumpang Perkotaan, maka dilakukan perbandingan seperti pada Tabel 2.

\section{Tabel 2 Tingkat Pelayanan Angkutan Umum AG}

Penilaian kinerja trayek berdasarkan perbandingan parameter penilaian kinerja trayek angkutan dengan standard pelayanan angkot (tabel 4.10), diketahui bahwa

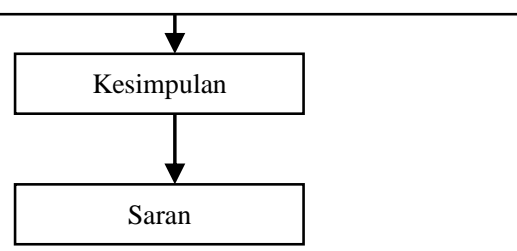

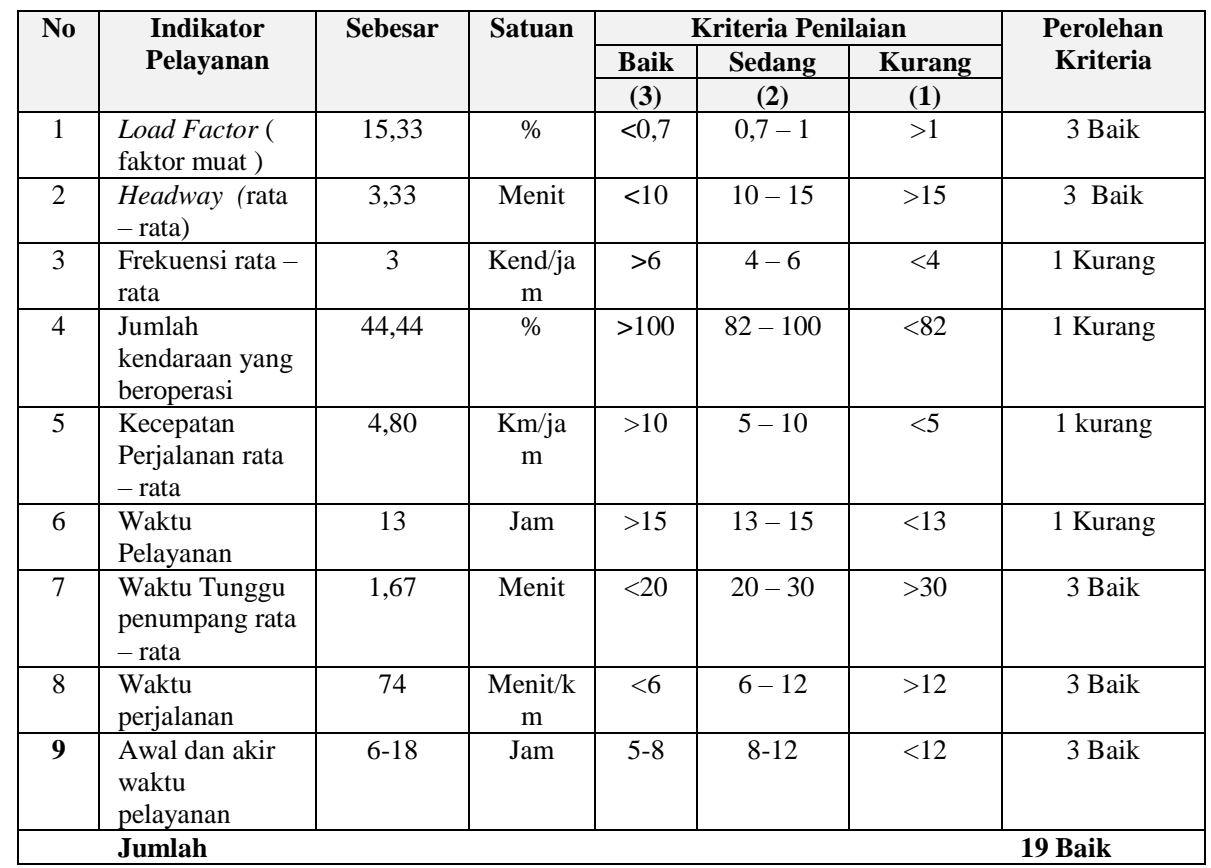


penilaian Load Factor, headway, frekuensi, Jumlah kendaraan yang beroperasi, Kecepatan perjalanan, waktu pelayanan, waktu tunggu penumpang, dan waktu perjalanan, Awal dan akhir waktu pelayanan pada angkutan umum penumpang trayek AG (Arjosari Gadang) termasuk kategori baik sesuai standard penilaian.

Sementara parameter frekuensi, jumlah kendaraan yang beroperasi, waktu pelayanan, Awal dan akhir waktu pelayanan termasuk kategori kurang pada standard penilaian angkutan umum berdasarkan standard Dishub. Dan untuk load factor, kecepatan perjalanan, dan waktu perjalanan termasuk kategori baik. Secara keseluruhan diperoleh nilai 19. Nilai tersebut diartikan bahwa secara keseluruhan tingkat pelayanan angkutan umum penumpang trayek AG (Arjosari - Gadang) berdasarkan standard pelayanan angkutan umum berdasarkan nilai bobot termasuk kriteria "Baik". Dari keseluruhan penilaian terhadap moda dan trayek angkutan, pada trayek AG (Arjosari - Gadang) diketahui bahwa kinerja pelayanan trayek yang tidak berjalan sesuai ketetapan tetap memberikan layanan yang baik walaupun parameter, frekuensi, jumlah kendaraan yang beroperasi, waktu pelayanan, dan Awal dan akhir waktu pelayanan termasuk kategori kurang.

\section{Penelitian Sebelum Pendemi}

Untuk mengetahui kesesuaian antara kinerja angkutan umum trayek AG ( Arjosari - Gadang ) dengan Peraturan Direktur Jenderal Perhubungan Darat Tahun 2002 tentang Petunjuk Teknis Penyelenggaraan Angkutan Penumpang Perkotaan, maka dilakukan perbandingan.

Penilaian kinerja trayek berdasarkan perbandingan parameter penilaian kinerja trayek angkutan dengan standard pelayanan angkot, diketahui bahwa penilaian Load Factor, headway, frekuensi, Jumlah kendaraan yang beroperasi, Kecepatan perjalanan, waktu pelayanan, waktu tunggu penumpang, dan waktu perjalanan pada angkutan umum penumpang trayek AG (Arjosari Gadang) termasuk kategori baik sesuai standard penilaian.

Sementara parameter jumlah kendaraan yang beroperasi, load factor, waktu pelayanan, termasuk kategori kurang pada standard penilaian angkutan umum berdasarkan standard Dishub. Dan untuk Frekuensi,headway,kecepatan perjalanan, dan waktu perjalanan termasuk kategori baik. Secara keseluruhan diperoleh nilai 20. Nilai tersebut diartikan bahwa secara keseluruhan tingkat pelayanan angkutan umum penumpang trayek AG (Arjosari - Gadang) berdasarkan standard pelayanan angkutan umum berdasarkan nilai bobot termasuk kriteria "Baik". Dari keseluruhan penilaian terhadap moda dan trayek angkutan, pada trayek AG (Arjosari - Gadang) diketahui bahwa kinerja pelayanan trayek yang tidak berjalan sesuai ketetapan tetap memberikan layanan yang baik walaupun parameter jumlah kendaraan yang beroperasi, waktu pelayanan termasuk kategori kurang.

Perbandigan antara penelitian sebelum dan masa pendemi covid 19 pada trayek AG (Arjosari - Gadang). Adalah penelitian saat covid 19 load factor 15,33\%,Headway 3,33 Menit, Frekuensi 3 kend/jam,
Jumlah kendaraan yang beroperasi $44,44 \%$, Waktu perjalanan 74 Menit/km Kecepatan perjalanan 4,80 $\mathrm{Km} / \mathrm{jam}$, Waktu pelayanan 13 jam dan Awal dan Akhir waktu pelayanan 6-18 jam. Waktu tunggu 1,67 Menit. Nilai tersebut diartikan bahwa secara keseluruhan tingkat pelayanan angkutan umum penumpang trayek AG (Arjosari - Gadang) berdasarkan standard pelayanan angkutan umum berdasarkan nilai bobot termasuk kriteria "Baik". Sedangkan sebelum covid 19 Adalah Load Factor 189,15\% , Headway 0,88 Menit, frekuensi $62 \mathrm{kend} / \mathrm{Jam}$, jumlah kendaraan yang beroperasi $53 \%$, kecepatan perjalanan 16,44 Km/jam, waktu pelayanan $12 \mathrm{Jam}$, Waktu Tunggu 2 Menit dan waktu perjalanan 58 Menit $/ \mathrm{km}$. Nilai tersebut diartikan bahwa secara keseluruhan tingkat pelayanan angkutan umum penumpang trayek AG (Arjosari - Gadang) berdasarkan standard pelayanan angkutan umum berdasarkan nilai bobot termasuk kriteria "Baik".

\section{B. Solusi Alternatif Untuk Meningkatkan Kinerja Pelayanan Angkutan Umum trayek AG (Arjosari- Gadang )}

Setelah mengetahui permasalahan kinerja pelayanan angkutan umum penumpang yang ada, selanjutnya dapat ditentukan solusi alternatif untuk meningkatkan kinerja pelayanan angkutan umum trayek AG (Arjosari- Gadang). Adapun solusi alternatif yang diusulkan penulis terdapat pada Tabel 3 :

Tabel 3 Solusi Masala Dari Parameter Kinerja Angkutan Umum

\begin{tabular}{|c|c|c|c|c|}
\hline No & $\begin{array}{c}\text { Parameter } \\
\text { Kinerja } \\
\text { Angkutan }\end{array}$ & Masalah & Solusi & Output \\
\hline 1 & Frekuensi & $\begin{array}{l}\text { Frekuinsi } \\
\text { terlalu } \\
\text { singkat } \\
\text { (kurang) }\end{array}$ & $\begin{array}{l}\text { Mengatur } \\
\text { kembali } \\
\text { waktu } \\
\text { frekuensi } \\
\text { - waktu } \\
\text { beropera } \\
\text { si } \\
\text { - waktu } \\
\text { perjalana } \\
\text { n }\end{array}$ & $\begin{array}{l}\text { Frekuensi sesuai } \\
\text { standar yang } \\
\text { ditentukan oleh } \\
\text { Peraturan Direktur } \\
\text { Jenderal Perhubungan } \\
\text { Darat Tahun } 2002 \\
\text { tentang Petunjuk } \\
\text { Teknis } \\
\text { Penyelenggaraan } \\
\text { Angkutan } \\
\text { Penumpang } \\
\text { Perkotaan }\end{array}$ \\
\hline 2 & $\begin{array}{l}\text { Jumlah } \\
\text { kendaraan } \\
\text { yang } \\
\text { beroperasi }\end{array}$ & $\begin{array}{l}\text { Jumlah } \\
\text { kendaraan } \\
\text { banyak } \\
\text { tetapi yang } \\
\text { beroperasi } \\
\text { optimal } \\
\text { kurang }\end{array}$ & $\begin{array}{l}\text { Mengatur } \\
\text { kembali } \\
\text { kendaraan } \\
\text { yang } \\
\text { beroperasi } \\
\text { - waktu } \\
\text { kendaraa } \\
\text { n } \\
\text { beropera } \\
\text { si } \\
\text { - standar } \\
\text { rit per } \\
\text { hari }\end{array}$ & $\begin{array}{l}\text { Jumlah kendaraan } \\
\text { yang beroperasi } \\
\text { sesuai standar yang } \\
\text { ditentukan oleh } \\
\text { Peraturan Direktur } \\
\text { Jenderal Perhubungan } \\
\text { Darat Tahun } 2002 \\
\text { tentang Petunjuk } \\
\text { Teknis } \\
\text { Penyelenggaraan } \\
\text { Angkutan } \\
\text { Penumpang } \\
\text { Perkotaan }\end{array}$ \\
\hline 3 & $\begin{array}{l}\text { Waktu } \\
\text { pelayanan }\end{array}$ & $\begin{array}{l}\text { Waktu } \\
\text { pelayaanan } \\
\text { masi } \\
\text { kurang } \\
\text { standsar }\end{array}$ & $\begin{array}{l}\text { Mengatur } \\
\text { kembali } \\
\text { waktu } \\
\text { pelayanan } \\
\text { - mengatu } \\
\text { r waktu } \\
\text { istrahat } \\
\text { - waktu } \\
\text { kendaraa } \\
\text { n yang } \\
\text { beropera } \\
\text { si }\end{array}$ & $\begin{array}{l}\text { Jumlah kendaraan } \\
\text { yang beroperasi } \\
\text { sesuai standar yang } \\
\text { ditentukan oleh } \\
\text { Peraturan Direktur } \\
\text { Jenderal Perhubungan } \\
\text { Darat Tahun } 2002 \\
\text { tentang Petunjuk } \\
\text { Teknis } \\
\text { Penyelenggaraan } \\
\text { Angkutan } \\
\text { Penumpang } \\
\text { Perkotaan }\end{array}$ \\
\hline
\end{tabular}




\begin{tabular}{|c|c|c|c|c|}
\hline \multicolumn{5}{|c|}{ Lanjutan Tabel 3} \\
\hline 4 & $\begin{array}{l}\text { Awal dan } \\
\text { akhir waktu } \\
\text { pelayana }\end{array}$ & $\begin{array}{l}\text { Waktu } \\
\text { pelayanan } \\
\text { masih } \\
\text { kurang } \\
\text { standar }\end{array}$ & $\begin{array}{l}\text { Mengatur } \\
\text { kembali } \\
\text { waktu } \\
\text { pelayanan } \\
\text { - waktu } \\
\text { operasi } \\
\text { - waktu } \\
\text { istrahat }\end{array}$ & $\begin{array}{l}\text { Awal dan akhir waktu } \\
\text { pelayanan yang } \\
\text { beroperasi sesuai } \\
\text { standar yang } \\
\text { ditentukan oleh } \\
\text { Peraturan Direktur } \\
\text { Jenderal Perhubungan } \\
\text { Darat Tahun 2002 } \\
\text { tentang Petunjuk } \\
\text { Teknis } \\
\text { Penyelenggaraan } \\
\text { Angkutan } \\
\text { Penumpang } \\
\text { Perkotaan }\end{array}$ \\
\hline
\end{tabular}

Sumber:Hasil Analisis 2020

\section{UCAPAN TERIMA KASIH}

Terima kasih kepada Allah SWT yang memberikan kesempatan, kesehatan dan kelancaran proses penelitian, Ucapan terima kasih juga kepada Dinas Perhubungan Kota Malang, Bappeda Kota Malang yang telah diperbolehkan untuk mengambil data dan melakukan penelitian. Tak lupa kepada semua pihak yang telah membantu dalam proses penelitian dari awal sampai dengan akhir.

\section{KESIMPULAN}

1) Hasil kinerja dari angkutan masa pendemi covid 19 trayek AG (Arjosari- Gadang ) antara lain : Jumlah penumpang rata-rata $=2$, Load factor $=$ $15,33 \%$, kecepatan perjalanan $=4,80 \mathrm{~km} / \mathrm{jam}$, waktu antara (Headway) $=3,33$ menit, waktu perjalanan $=4,56$ menit $/ \mathrm{km}$, waktu pelayanan $=13$ jam/hari, jumlah kendaraan yang beroperasi = $44,44 \%$, waktu tunggu penumpang $=1,67$ menit dan awal dan akhir pelayanan $=06: 30-18: 00$ WIB. Dengan kategori penilaian BAIK. Adapun beberapa tingkat pelayanan yang keriteria kurang seperti waktu pelayanan, dan Awal dan akhir waktu pelayanan. Hasil kinerja dari angkutan sebebelum covid 19 trayek AG (Arjosari- Gadang) antara lain : Load factor $=189,15 \%$, kecepatan perjalanan $=4,80 \mathrm{~km} / \mathrm{jam}$, waktu antara (Headway) $=0,88$ menit, Frekuensi $62 \mathrm{ken} / \mathrm{jam}$, waktu perjalanan $=16,44$ menit $/ \mathrm{km}$, waktu pelayanan $=12 \mathrm{jam} /$ hari, jumlah kendaraan yang beroperasi $=53 \%$, waktu tunggu penumpang $=2$ menit. Dengan kategori penilaian BAIK. walaupun ada beberapa tingkat pelayanan yang kriteria kurang seperti Load Factor, jumlah kendaraan yang beroperasi, waktu pelayanan.

2) Solusi Alternatif Kinerja Angkutan Umum

a. Frekuensi

Mengatur kembali waktu frekuinsi dengan

cara waktu beroperasi,waktu perjalanan

b. Jumlah Kendaraan yang Beroperasi

Mengatur kembali kendaraan yang

beroperasi dengan cara waktu kendaraan

beroperasi, standar rit per hari c. Waktu Pelayanan

Mengatur kembali waktu pelayanan dengan cara mengatur waktu istirahat, waktu kendaraan.

d. Awal dan Akir Waktu Pelayanan Mengatur kembali Awal dan Akir Waktu Pelayanan dari segi waktu beroperasi dan waktu istirahat.

\section{DAFTAR PUSTAKA}

Asikin, Muslich Zainal.2001. Sistem Manajemen Transportasi Kota. Yogyakarta : Penerbit UGM.

Undang - undang No. 22 tahun 2009, Tentang Lalu Lintas dan Angkutan Jalan. Peraturan Pemerintah Nomor 74 Tahun 2014 Tentang Angkutan Jalan.

Keputusan Direktorat Jenderal Perhubungan Darat Nomor SK. 678/AJ. 206/DRJD/2002. Tentang Pedoman Teknis Penyelenggaraan Angkutan Umum Penumpang Umum Diwilayah Perkotaan Dalam Trayek Tetap dan Teratur.

Direktorat Jenderal Perhubungan Darat,(2002), Pedoman Teknis Penyelengaraan Angkutan Umum di Wilayah Perkotaan dalm Trayek Tetap dan Teratur.

Direktorat Jenderal Perhubungan Darat, (2002), Panduan Pengumpulan Data Angkutan Umum Perkotaan.

Direktorat Jenderal Perhubungan Darat,(1996), Pedoman Teknis Penyelenggaraan Angkutan Penumpang Umum di Wilayah Perkotaan dalam Trayek Tetap dan Teratur.

Direktorat Jenderal Perhubungan Darat, (1995), Мепијu Lalu Lintas dan Angkutan Jalan Yang Tertip.

Morlok, E.K,(1978), Pengantar Teknik dan Perencanaan Transportasi, Terjemahan oleh Johan Kelanaputra Hainim 1985. Penerbit Erlangga, Jakarta.

Nasution, H.M.N., (2008), Manajemen Transportasi, Ghalia Indonesia, Jakarta. Tamin, O.Z, (1997), Perencanaan dan Permodelan Transportasi, penerbit ITB, Bandung.

Warpani, Suwardjoko. (2002), Pengolahan Lalu Lintas dan Angkutan Jalan, Penerbit ITB, Bandung. 


\title{
Pengaruh Penerapan K3 (Keselamatan dan Kesehatan Kerja) Pada Pembangunan Laboratorium Komputer SMP It Al-Haromain, SMPS Darul Ulum, Dan SMP Badrul Ulum
}

\author{
Dedy Asmaroni ${ }^{1}$ dan Ahmad Fatoni ${ }^{2}$ \\ ${ }^{1}$ Program Studi Teknik Sipil, Fakultas Teknik, Universitas Madura, Pamekasan \\ ${ }^{2}$ Program Studi Teknik Sipil, Fakultas Teknik, Universitas Madura, Pamekasan \\ E-mail: dedyasmaroni@gmail.com
}

\begin{abstract}
ABSTRAK: Dalam mewujudkan suatu pembangunan konstruksi yang baik, tentunya kita harus melihat keselamatan dan kesehatan kerja (K3). Karena secara umum proyek pembangunan direncanakan untuk mendirikan sebuah gedung yang berfungsi untuk kepentingan orang banyak, dimana pembangunan tersebut memiliki standart pembangunan gedung berbasis pemerintah dan semaksimal mungkin dalam pelaksanaan tersebut tidak mengalami resiko-resiko yang mempengaruhi dalam pekerjaan, khususnya pada keselamatan dan kesehatan kerja (K3) pada pembangunan konstruksi gedung. Pada Penelitian ini membahas mengenai pengaruh penerapan keselamatan dan kesehatan kerja (K3) terhadap kinerja pekerja proyek konstruksi pembangunan ruang laboratorium komputer SMP IT Al-Haromain, SMPS Darul Ulum dan SMP Badrul Ulum. Dari hasil Uji t : Ketiga variabel tidak berpengaruh terhadap variabel (Y), sedangkan dari hasil uji f didapat Kecelakaan Kerja memiliki pengaruh yang paling dominan terhadap Pengaruh K3 Terhadap Produktivitas Pekerja pada proyek Pembangunan Laboratorium Komputer di Kabupaten Pamekasan.
\end{abstract}

\section{PENDAHULUAN}

\section{1) Latar Belakang}

Pembangunan proyek konstruksi bangunan gedung di indonesia provinsi jawa timur khususnya di wilayah pamekasan madura. Setiap proyek konstruksi selalu di hadapkan pada kemungkinan terjadinya berbagai macam resiko. Semakin tinggi tingkat kompleksitas suatu proyek, maka semakin besar pula tingkat resiko yang akan di terima. Resiko ini akan memberikan pengaruh terhadap keselamatan dan kesehatan kerja (K3) dalam pelaksanaan proyek itu sendiri.

Dalam mewujudkan suatu pembangunan konstruksi yang baik, tentunya kita harus melihat keselamatan dan kesehatan kerja (K3). Karena secara umum proyek pembangunan direncanakan untuk mendirikan sebuah gedung yang berfungsi untuk kepentingan orang banyak, dimana pembangunan tersebut memiliki standart pembangunan gedung berbasis pemerintah dan semaksimal mungkin dalam pelaksanaan tersebut tidak mengalami resiko-resiko yang mempengaruhi dalam pekerjaan, khususnya pada keselamatan dan kesehatan kerja (K3) pada pembangunan konstruksi gedung.

Dalam pembangunan tentunya ada resiko keselamatan dan kesehatan kerja (K3), hal ini dapat di katakan suatu akibat yang mungkin terjadi secara tidak terduga pada suatu proyek. Walaupun suatu kegitan telah di rencanakan sebaik mungkin, namun tetap mengandung ke tidak pastian pada suatu proyek untuk tidak terkendala oleh keselamatan dan kesehatan kerja. Karena resiko pada suatu proyek tidak dapat di hilangkan akan tetapi bisa di kurangi atau di minimalisir.

Keselamatan dan kesehatan kerja (K3) merupakan salah satu faktor penting agar tercapai kualitas produk yang baik dan tercapainya keselamatan kerja dalam pelaksanaan suatu pekerjaan yang terjamin, sehingga kesejahteraan pekerja dapat lebih ditingkatkan. Sistem keselamatan dan kesehatan kerja (K3) yang baik dapat meminimalkan resiko terjadinya kecelakaan kerja yang menimpa fisik ataupun mental dari pekerja.

Perusahaan merupakan spesialisasi dalam ilmu kesehatan beserta prakteknya dengan mengadakan penilaian kepada faktor-faktor penyebab penyakit dalam lingkungan kerja dan perusahaan melalui pengukuran yang hasilnya dipergunakan untuk dasar tindakan korektif dan bila perlu pencegahan kepada lingkungan tersebut, agar pekerja dan masyarakat sekitar perusahaan terhindar dari bahaya akibat kerja, serta dimungkinkan untuk mengecap derajat kesehatan setinggi-tinginya (Anies, 2005).

Pelaksanaan keselamatan dan kesehatan kerja adalah suatu kondisi dalam pekerjaan yang sehat dan aman baik itu bagi pekerjaannya, perusahaan maupun bagi masyarakat dan lingkungan sekitar pabrik atau tempat kerja tersebut. Keselamatan dan kesehatan kerja juga merupakan suatu usaha untuk mencegah setiap perbuatan atau kondisi tidak selamat, yang dapat mengakibatkan kecelakaan.

Keselamatan dan kesehatan kerja (K3) sebagai salah satu aspek perlindungan tenaga kerja memiliki peran yang 
besar dalam upaya meningkatkan produktivitas perusahaan (Sedarmayanti, 2009).

Menyadari pentingnya keselamatan dan kesehatan kerja (K3) agar dapat memberi rasa aman dan mencegah kecelakaan kerja sehingga dapat meningkatkan semangat ataupun kinerja para pekerja lainnya. Penelitian membahas mengenai pengaruh penerapan keselamatan dan kesehatan kerja (K3) terhadap kinerja pekerja proyek konstruksi pembangunan ruang laboratorium komputer SMP IT Al-Haromain, SMPS Darul Ulum dan SMP Badrul Ulum.

\section{METODE PENELITIAN}

Langkah-langkah pada penelitian ini terdapat pada diagram alir Gambar 1.

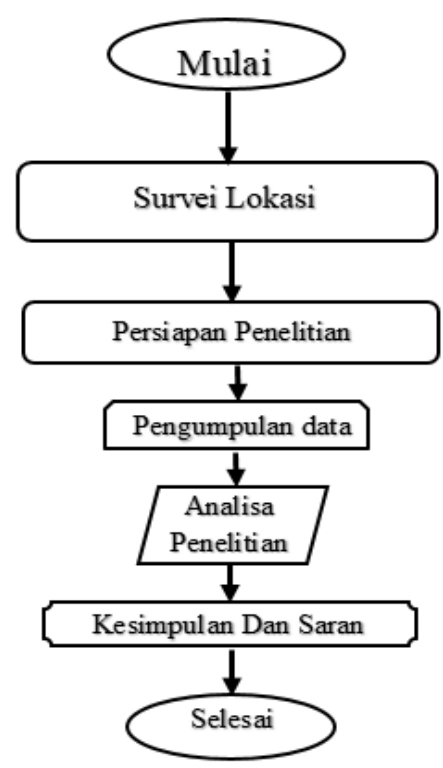

Gambar 1. Diagaram Alir Penelitian

\section{HASIL PENELITIAN DAN PEMBAHASAN}

\section{1) Pengumpulan Data}

Penelitian telah dilakukan terhadap 25 responden. Pengumpulan data dilakukan dengan membagikan kuesioner. Untuk membantu dan memperjelas jawaban dari pertanyaan dilakukan juga wawancara kepada beberapa pekerja yang telah mengisi kuisioner.

Pelaksanaan pengumpulan data penelitian dilakukan pada tiga proyek Pembangunan Laboratorium komputer di Kabupaten Pamekasan.

- SMPS Darul Ulum, Kec. Waru, Sana Laok, Kabupaten Pamekasan sebanyak 10 responden.

- SMPI Badrul Ulum, Kec. Waru, Du'uman, Kabupaten Pamekasan sebanyak 10 responden
SMP It Al-haromain Kec. Pasean, Batu Kerbuy, Kabupaten Pamekasan sebanyak 5 responden.

\section{2) Uji Validitas}

Hipotesis : $\mathrm{H}_{0} \quad$ : Data yang diperoleh telah valid

$\mathrm{H}_{1} \quad$ : Data yang diperoleh tidak valid

Pengambilan Keputusan :

Jika pearson correlate $\geq \mathrm{r}$ tabel maka terima $\mathrm{H}_{0}$

Jika pearson correlate $<\mathrm{r}$ tabel maka terima $\mathrm{H}_{1}$

Berikut ini merupakan hasil menghitung $\mathrm{r}$ :

\section{- Data Informasi Statistik Keselamatn Kerja} (X1)

Tabel 1 Data Informasi Statistik Keselamatan Kerja (X1)

\begin{tabular}{|c|c|c|c|c|c|}
\hline \multirow{2}{*}{ Variabel } & Indikator & $\begin{array}{c}\text { Koefisien } \\
\text { Korelasi }\end{array}$ & $\begin{array}{c}\text { Nilai r } \\
\text { Tabel }\end{array}$ & $p$-value & Hasil \\
\hline \multirow{2}{*}{$\begin{array}{c}\text { Keselamatan } \\
\text { Kerja } \\
\text { (X1) }\end{array}$} & X1.A1 & 0,681 & 0,396 & 0,000 & Valid \\
\cline { 2 - 6 } & X1.A2 & 0,548 & 0,396 & 0,000 & Valid \\
\cline { 2 - 6 } & X1.A3 & 0,745 & 0,396 & 0,000 & Valid \\
\hline
\end{tabular}

Tabel 1 merupakan hasil pengujian validitas Keselamatan Kerja (X1) menggunakan software SPSS. Dari data Keselamatan Kerja (X1), pertanyaan X1.A1, $\mathrm{X} 1 . \mathrm{A} 2$ dan X1.A3 diperoleh nilai koefisien korelasi lebih besar dari $r$ tabel yaitu 0,396 sehingga dapat diputuskan bahwa data terima hipotesa nol dan kesimpulannya yaitu data yang diperoleh telah valid.

\section{- Data Informasi Statistik Kesehatan Kerja (X2)}

Tabel 2 Data Informasi Statistik Kesehatan Kerja (X2)

\begin{tabular}{|c|c|c|c|c|c|}
\hline Variabel & Indikator & $\begin{array}{c}\text { Koefisien } \\
\text { Korelasi }\end{array}$ & $\begin{array}{c}\text { Nilai r } \\
\text { Tabel }\end{array}$ & $p$-value & Hasil \\
\hline $\begin{array}{c}\text { Kesehatan } \\
\text { Keja } \\
(\mathrm{X} 2)\end{array}$ & $\mathrm{X} 2 . \mathrm{B} 1$ & 0,722 & 0,396 & 0,000 & Valid \\
\cline { 2 - 6 } & $\mathrm{X} 2 . \mathrm{B} 2$ & 0,765 & 0,396 & 0,000 & Valid \\
\hline
\end{tabular}

Tabel 2 merupakan hasil pengujian validitas Kesehatan Kerja (X2) menggunakan software SPSS. Dari data Kesehatan Kerja (X2), pertanyaan X2.B1 dan X2.B2 diperoleh nilai koefisien korelasi lebih besar dari $\mathrm{r}$ tabel yaitu 0,396 sehingga dapat diputuskan bahwa data terima 
hipotesa nol dan kesimpulannya yaitu data yang diperoleh telah valid.

\section{- Data Informasi Statistik Kecelakaan Kerja (X3)}

Tabel 3 Data Informasi Statistik Kecelakaan Kerja (X3)

\begin{tabular}{|c|c|c|c|c|c|}
\hline Variabel & Indikator & $\begin{array}{c}\text { Koefisien } \\
\text { Korelasi }\end{array}$ & $\begin{array}{c}\text { Nilai r } \\
\text { Tabel }\end{array}$ & $p$-value & Hasil \\
\hline \multirow{2}{*}{$\begin{array}{c}\text { Kecelakaan } \\
\text { Kerja } \\
\text { (X3) }\end{array}$} & X3.C1 & 0,812 & 0,396 & 0,000 & Valid \\
\cline { 2 - 6 } & X3.C2 & 0,926 & 0,396 & 0,000 & Valid \\
\hline
\end{tabular}

Tabel 3 merupakan hasil pengujian validitas Upah Bulanan (X3) menggunakan software SPSS. Dari data Metode Pelaksanaan (X3), pertanyaan X3.C1 dan X3.C2 diperoleh nilai koefisien korelasi lebih besar dari $r$ tabel yaitu 0,396 sehingga dapat diputuskan bahwa data terima hipotesa nol dan kesimpulannya yaitu data yang diperoleh telah valid.

\section{- Data Informasi Statistik PK3TPP (Y)}

Tabel 4 Data Informasi Statistik PK3TPP (Y)

\begin{tabular}{|c|c|c|c|c|c|}
\hline Variabel & Indikator & $\begin{array}{c}\text { Koefisien } \\
\text { Korelasi }\end{array}$ & $\begin{array}{c}\text { Nilai r } \\
\text { Tabel }\end{array}$ & $p$-value & Hasil \\
\hline $\begin{array}{c}\text { PK3TPP } \\
\text { (X4) }\end{array}$ & Y.D1 & 1,000 & 0,396 & 0,000 & Valid \\
\hline
\end{tabular}

Tabel 4 merupakan hasil pengujian validitas Pengaruh Keselamatan, Kesehatan dan Kecelakaan Kerja Terhadap Produktivitas Pekerja (Y) menggunakan software SPSS. Dari data PK3TPP (X4), pertanyaan Y1.D1. diperoleh nilai koefisien korelasi lebih besar dari $r$ tabel yaitu 0,396 sehingga dapat diputuskan bahwa data terima hipotesa nol dan kesimpulannya yaitu data yang diperoleh telah valid.

\section{3) Uji Reliabilitas}

Tabel 5 Hasil Uji Reliabilitas

\begin{tabular}{|l|l|c|c|l|}
\hline \multirow{2}{*}{ Variabel } & Indikator & $\begin{array}{c}\text { N on } \\
\text { Items }\end{array}$ & $\begin{array}{c}\text { Cronbach's } \\
\text { Alpha }\end{array}$ & Keterangan \\
\hline \multirow{2}{*}{$\mathrm{X}$} & Keselamatan kerja & 4 & 0,746 & Reliabel \\
\cline { 2 - 5 } & Kesehatan Kerja & 3 & 0,786 & Reliabel \\
\cline { 2 - 5 } & Kecelakaan Kerja & 3 & 0,903 & Reliabel \\
\hline Y & PK3TPP & 2 & 1,000 & Reliabel \\
\hline
\end{tabular}

Dari keterangan pada Tabel 4.5 di atas dapat diketahui bahwa masing-masing variabel memiliki Cronbach Alpha $>0,60$. Dengan demikian variabel X dan variabel Y dapat dikatakan reliabel.

\section{4) Asumsi Klasik}

\section{- Uji Normalitas}

Tabel 6 Uji Normalitas

\begin{tabular}{|l|c|}
\hline \multicolumn{1}{|c|}{$\begin{array}{c}\text { Uji kolmogorov- } \\
\text { smirnov }\end{array}$} & Unstandarize Residual \\
\hline $\begin{array}{l}\text { Nilai kolmogorov- } \\
\text { smirnov }\end{array}$ & 0,890 \\
\hline Sig & $0,200^{\mathrm{c}, \mathrm{d}}$ \\
\hline
\end{tabular}

Berdasarkan pada Tabel 6, uji Kolomorov Smirnov menunjukkan bahwa residual data yang didapat tersebut mengikuti distribusi normal, berdasarkan hasil output menunjukkan nilai Kolmogorov-Smirnov signifikan pada 0,200 >0,05. Dengan demikian, residual data berdistribusi normal dan model regresi telah memenuhi asumsi normalitas.

\section{- Uji Multikolinearitas}

Tabel 7 Uji Multikolinearitas

\begin{tabular}{|l|l|l|}
\hline \multirow{2}{*}{ Mode1 } & \multicolumn{2}{|c|}{$\begin{array}{l}\text { Collinearity } \\
\text { Statistic }\end{array}$} \\
\cline { 2 - 3 } & Tolerance & VIF \\
\hline (Constant) & & \\
\hline X1 (Keselamatan Kerja) & 0,643 & 1,555 \\
\hline X2 (Kesehatan Kerja) & 0,949 & 1,054 \\
\hline X3 (Kecelakaan Kerja) & 0,651 & 1,536 \\
\hline
\end{tabular}

Dari hasil pengujian multikolinearitas yang ada pada Tabel 7 diketahui bahwa nilai variance inflation factor (VIF) ke tiga variabel, yaitu lebih kecil dari 10 dan nilai tolerance lebih besar dari 0,10, sehingga dapat disimpulkan bahwa tidak ada multikolinearitas antar variabel independent dalam model regresi. 


\section{- Uji Heteroskedastisitas}

Tabel 8 Uji Heteroskedastisitas

\begin{tabular}{|l|l|l|}
\hline Variabel & Sig & Kriteria \\
\hline $\mathrm{X}_{1}$ & 0,148 & Tidak terjadi heteroskedastisitas \\
\hline $\mathrm{X}_{2}$ & 0,737 & Tidak terjadi heteroskedastisitas \\
\hline $\mathrm{X}_{3}$ & 0,106 & Tidak terjadi heteroskedastisitas \\
\hline
\end{tabular}

Berdasarkan Tabel 8 uji heteroskedastisitas dengan metode glejser tidak ada variabel yang terjadi heteroskedastisitas karena diperoleh nilai signifikansi lebih besar 0,05 , sehingga dapat disimpulkan data tidak terjadi masalah heteroskedastisitas.

\section{- Uji Autokorelasi}

Tabel 9 Uji Autokorelasi

\begin{tabular}{|c|c|c|c|c|c|}
\hline Model & R & R Square & $\begin{array}{c}\text { Adjusted R } \\
\text { Square }\end{array}$ & $\begin{array}{c}\text { Std. Error of the } \\
\text { Estimate }\end{array}$ & $\begin{array}{c}\text { Durbin- } \\
\text { Watson }\end{array}$ \\
\hline 1 & 0,357 & 0,128 & 0,003 & 0,76254 & 2,387 \\
\hline
\end{tabular}

Berdasarkan nilai uji statistik Durbin-Watson pada Tabel 9 dalam penelitian ini yaitu 2,387, selanjutnya dibandingkan dengan nilai tabel signifikan 5\% $(0,05)$ dengan jumlah sampel 25 dan jumlah variabel independent $3(\mathrm{~K}=3)=5,24$ sehingga didapatkan hasil $\mathrm{dU}$ dari tabel $\mathrm{r}=$ 1,902. Nilai dL 1,228 lebih kecil dari batas dU 1,6540 kurang dari (4$\mathrm{dU})=4-1,6540=2,346$. Sehingga dapat disumpulkan bahwa tidak terjadi autocorrelation.

\section{5) Analisa Deskriptif}

\section{- Keselamatan Kerja (X1)}

Tabel 10 Uji Analisa Deskriptif Keselamatan Kerja

\begin{tabular}{|l|r|r|r|r|r|r|}
\hline \multirow{2}{*}{ Pernyataan } & \multicolumn{5}{|c|}{ Variabel Keselamatan Kerja (X1) } \\
\cline { 2 - 7 } & \multicolumn{2}{|c|}{ X1.A1 } & \multicolumn{2}{|c|}{ X1.A2 } & \multicolumn{2}{|c|}{ X1.A3 } \\
\cline { 2 - 7 } & $\begin{array}{r}\text { Freque } \\
\text { ncy }\end{array}$ & $\begin{array}{r}\text { Perc } \\
\text { ent } \\
(\%)\end{array}$ & $\begin{array}{c}\text { Freque } \\
\text { ncy }\end{array}$ & $\begin{array}{r}\text { Perc } \\
\text { ent } \\
(\%)\end{array}$ & $\begin{array}{r}\text { Freque } \\
\text { ncy }\end{array}$ & $\begin{array}{r}\text { Perc } \\
\text { ent } \\
(\%)\end{array}$ \\
\hline $\begin{array}{l}\text { Sangat Tidak } \\
\text { Setuju }\end{array}$ & 1 & 4,0 & - & - & - & - \\
\hline Tidak Setuju & 2 & 8,0 & 7 & 28,0 & 4 & 16,0 \\
\hline Ragu-Ragu & 6 & 24,0 & 11 & 44,0 & 5 & 20,0 \\
\hline Setuju & 14 & 56,0 & 7 & 28,0 & 14 & 56,0 \\
\hline $\begin{array}{l}\text { Sangat } \\
\text { Setuju }\end{array}$ & 2 & 8,0 & - & - & 2 & 8,0 \\
\hline Total & 25 & 100, & 25 & 100, & & 100, \\
\hline
\end{tabular}

Berdasarkan Tabel 10 maka didapat untuk pernyataan pertama X1.A1 sebanyak 14 responden lebih berpendapat setuju dengan persentase 56\%. Untuk pernyataan kedua X1.A2 sebanyak 11 responden yang menjawab ragu-ragu dengan persentase $44 \%$ dan Untuk pernyataan ketiga X1.A3 sebanyak 14 responden yang menjawab setuju dengan persentase $56 \%$.

\section{- Kesehatan Kerja (X2)}

Berdasarkan Tabel 12 maka didapat untuk pernyataan pertama X2.B1 sebanyak 15 responden lebih berpendapat setuju dengan persentase $60 \%$. Untuk pernyataan kedua X2.B2 sebanyak 11 responden yang menjawab setuju dengan persentase $44 \%$.

Tabel 11 Uji Analisa Deskriptif Kesehatan Kerja

\begin{tabular}{|l|r|r|r|r|}
\hline \multirow{2}{*}{\multicolumn{1}{|c|}{ Pernyataan }} & \multicolumn{4}{|c|}{ Variabel Kesehatan Kerja (X2) } \\
\cline { 2 - 5 } & \multicolumn{2}{|c|}{ X2.B2 } & \multicolumn{2}{c|}{ X2.B2 } \\
\cline { 2 - 5 } & Frequency & $\begin{array}{c}\text { Percent } \\
(\%)\end{array}$ & Frequency & $\begin{array}{c}\text { Percent } \\
\text { (\%) }\end{array}$ \\
\hline Sangat Tidak Setuju & 1 & 4,0 & 1 & 4,0 \\
\hline Tidak Setuju & 9 & 36,0 & 7 & 28,0 \\
\hline Ragu-Ragu & 5 & 20,0 & 6 & 24,0 \\
\hline Setuju & 9 & 36,0 & 8 & 32,0 \\
\hline Sangat Setuju & 1 & 4,0 & 3 & 12,0 \\
\hline Total & 25 & 100,0 & 25 & 100,0 \\
\hline
\end{tabular}

Berdasarkan Tabel 11 maka didapat untuk pernyataan pertama X2.B1 sebanyak 9 responden lebih berpendapat setuju dan 9 responden tidak setuju dengan persentase $56 \%$. Untuk pernyataan kedua X2.B2 sebanyak 8 responden yang menjawab setuju dengan persentase $44 \%$.

\section{- Kecelakaan Kerja (X3)}

Tabel 12 Uji Analisa Deskriptif Kecelakaan Kerja

\begin{tabular}{|l|r|r|r|r|}
\hline \multirow{2}{*}{ Pernyataan } & \multicolumn{4}{|c|}{ Variabel Kecelakaan Kerja (X3) } \\
\cline { 2 - 5 } & \multicolumn{2}{|c|}{ X3.C1 } & \multicolumn{2}{c|}{ X3.C2 } \\
\cline { 2 - 5 } & Frequency & $\begin{array}{c}\text { Percent } \\
(\%)\end{array}$ & Frequency & $\begin{array}{c}\text { Percent } \\
(\%)\end{array}$ \\
\hline $\begin{array}{l}\text { Sangat Tidak } \\
\text { Setuju }\end{array}$ & - & - & 1 & 4,0 \\
\hline Tidak Setuju & 1 & - & 2 & 8,0 \\
\hline Ragu-Ragu & 15 & 60,0 & 11 & 44,0 \\
\hline Setuju & 9 & 36,0 & 1 & 4,0 \\
\hline Sangat Setuju & 25 & 100,0 & 25 & 100,0 \\
\hline Total & & - & 10 & 40,0 \\
\hline
\end{tabular}




\section{- Pengaruh K3 Terhadap Produktivitas Pekerja (Y)}

Berdasarkan Tabel 13 maka didapat untuk pernyataan Y1.D1 sebanyak 13 responden dengan persentase 52\% menjawab setuju.

Tabel 13 Uji Analisa Deskriptif Pengaruh K3 Terhadap Produktivitas Pekerja (Y)

\begin{tabular}{|l|r|r|}
\hline \multirow{2}{*}{\multicolumn{1}{|c|}{ Pernyataan }} & \multicolumn{2}{|c|}{ PK3TPP (Y) } \\
\cline { 2 - 3 } & \multicolumn{2}{|c|}{ Y1.D1 } \\
\cline { 2 - 3 } & Frequency & $\begin{array}{c}\text { Percent } \\
\text { (\%) }\end{array}$ \\
\hline Sangat Tidak Setuju & - & - \\
\hline Tidak Setuju & 1 & 4,0 \\
\hline Ragu-ragu & 7 & 28,0 \\
\hline Setuju & 13 & 52,0 \\
\hline Sangat Setuju & 4 & 16,0 \\
\hline Total & 25 & 100,0 \\
\hline
\end{tabular}

\section{6) Uji Regresi Linier Berganda}

Dari hasil perhitungan analisis regresi linier ganda pada Tabel 14 diperoleh koefisien masing-masing variabel dan dapat disusun persamaan linier berganda sebagai berikut :

$$
\mathrm{Y}=\mathrm{b} 0+\mathrm{b} 1 \cdot \mathrm{X}_{1}+\mathrm{b} 2 \cdot \mathrm{X}_{2}+\mathrm{b} 3 \cdot \mathrm{X}_{3}
$$

Maka persamaan tersebut menjadi :

$$
\begin{aligned}
& Y=2,066+-0,083 X_{1}+-0,197 X_{2}+- \\
& 0,366 X_{3}
\end{aligned}
$$

\begin{tabular}{|c|c|c|c|c|c|c|}
\hline & \multirow[t]{2}{*}{ Model } & \multicolumn{2}{|c|}{$\begin{array}{c}\text { Unstandardized } \\
\text { Coefficients }\end{array}$} & $\begin{array}{c}\text { Standardiz } \\
\text { ed } \\
\text { Coefficient } \\
\text { \& }\end{array}$ & \multirow[t]{2}{*}{$\mathrm{T}$} & \multirow[t]{2}{*}{ Sig. } \\
\hline & & B & $\begin{array}{l}\text { Std. } \\
\text { Error }\end{array}$ & Beta & & \\
\hline \multirow[t]{4}{*}{1} & (Constant) & 2,066 & 1,256 & & 1,645 & 0,115 \\
\hline & X1 (Keselamatan Kerja) & $-0,083$ & 0,344 & $-0,061$ & $-0,242$ & 0,812 \\
\hline & X2 (Kesehatan Kerja) & $-0,197$ & 0,199 & $-0,207$ & 0,990 & 0,334 \\
\hline & X3 (Kecelakaan Kerja) & $\begin{array}{c}- \\
0,366\end{array}$ & 0,309 & $-0,299$ & 1,184 & 0,250 \\
\hline
\end{tabular}

Tabel 14 Uji Regresi Linier Berganda

\section{- Uji Parsial atau Uji t}

Uji parsial atau uji t dilakukan dengan meliputi variabel terikat dan variabel bebas. Untuk variabel bebas terdiri dari Keselamatan Kerja, Kesehatan Kerja dan
Kecelakaan Kerja sedangkan untuk variabel terikat yaitu PK3TPP. Untuk hasil uji sendiri terdapat pada Tabel 15

\begin{tabular}{|c|c|c|c|}
\hline \multicolumn{2}{|r|}{ Model } & $\mathrm{T}$ & Sig. \\
\hline \multirow[t]{4}{*}{1} & (Constant) & 1,645 & 0,115 \\
\hline & $\begin{array}{l}\text { X1 (Keselamatan } \\
\text { Kerja) }\end{array}$ & $-0,242$ & 0,812 \\
\hline & $\begin{array}{ll}\text { X2 } & \text { (Kesehatan } \\
\text { Kerja) } & \end{array}$ & 0,990 & 0,334 \\
\hline & $\begin{array}{l}\text { X3 (Kecelakaan } \\
\text { Kerja) }\end{array}$ & 1,184 & 0,250 \\
\hline
\end{tabular}
berikut

Tabel 15 Nilai $t_{\text {Hiung }}$

Berdasarkan hasil dari Tabel 15 didapat nilai $t_{\text {hitung }}$ untuk variabel $X 1$ yaitu $-0,242$, sedangkan $t_{\text {tabel }}$ dengan menggunakan $\alpha / \mathrm{k}=0,05 / 5=0,01$ diketahui df $: \mathrm{n}$ $-\mathrm{k}-1=25-3-1=21$ adalah sebesar 2,518. Berdasarkan hasil tersebut maka $t_{\text {hitung }}(-0,242)<\mathrm{t}_{\text {tabel }}$ $(2,518)$. Berdasar pada hasil tersebut dapat diambil kesimpulan bahwa hipotesa 0 tidak dapat diterima, sehingga hipotesis "tidak pengaruh variabel Keselamatan Kerja (X1) terhadap variabel PK3TPP (Y1) " dapat diterima. Hal tersebut berarti bahwa variabel Keselamatan Kerja (X1) tidak berpengaruh terhadap variabel terikat yaitu PK3TPP (Y1).

\section{Analisa Uji Parsial atau Uji t Variabel X2}

Berdasarkan hasil dari Tabel 4.15 didapat nilai $t_{\text {hitung }}$ untuk variabel $\mathrm{X} 2$ yaitu 0,990 , sedangkan $t_{\text {tabel }}$ dengan menggunakan $\alpha / \mathrm{k}=0,05 / 5=0,01$ diketahui $\mathrm{df}: \mathrm{n}$ $-\mathrm{k}-1=25-3-1=21$ adalah sebesar 2,518. Berdasarkan hasil tersebut maka $t_{\text {hitung }}(0,990)<t_{\text {tabel }}$ $(2,518)$. Berdasar pada hasil tersebut dapat diambil kesimpulan bahwa hipotesa 0 dapat diterima, sehingga hipotesis "tidak ada pengaruh variabel Kesehatan Kerja (X2) terhadap variabel PK3TPP (Y1)" dapat diterima. Hal tersebut berarti bahwa variabel Kesehatan Kerja (X2) tidak berpengaruh terhadap variabel terikat yaitu PK3TPP (Y1).

\section{Analisa Uji Parsial atau Uji t Variabel X3}

Berdasarkan hasil dari Tabel 15 didapat nilai $t_{\text {hitung }}$ untuk variabel X3 yaitu 1,184, sedangkan $t_{\text {tabel }}$ dengan menggunakan $\alpha / \mathrm{k}=0,05 / 5=0,01$ diketahui df $: \mathrm{n}$ $-\mathrm{k}-1=25-3-1=21$ adalah sebesar 2,518. Berdasarkan hasil tersebut maka $t_{\text {hitung }}(1,184)<t_{\text {tabel }}$ (2,518). Berdasar pada hasil tersebut dapat diambil kesimpulan bahwa hipotesa 0 dapat diterima, sehingga hipotesis "tidak ada pengaruh variabel Kecelakaan Kerja (X3) terhadap variabel PK3TPP (Y1)" dapat diterima. Hal tersebut berarti bahwa variabel Kecelakaan Kerja (X3) tidak berpengaruh terhadap variabel terikat yaitu kualitas pekerjaan. 


\section{7) Uji Koefisien Determinasi Berganda}

Uji ini digunakan untuk menentukan persentase total variasi dalam variabel terikat yang diterangkan oleh variabel bebas, secara bersama-sama. Berikut hasil uji pada Tabel 16 menggunakan software SPSS :

Tabel 16 Model Summary

\begin{tabular}{|l|c|r|r|r|}
\hline Model & $\mathrm{R}$ & $\begin{array}{c}\mathrm{R} \\
\text { Square }\end{array}$ & $\begin{array}{c}\text { Adjusted } \\
\mathrm{R} \\
\text { Square }\end{array}$ & $\begin{array}{c}\text { Std. Error of } \\
\text { the Estimate }\end{array}$ \\
\hline 1 & $0,357^{\mathrm{a}}$ & 0,128 & 0,003 & 0,76254 \\
\hline
\end{tabular}

Dari Tabel 4.16 dapat diketahui hasil nilai koefisien determinasi berganda $\left(\mathrm{R}^{2}\right)$ dari analisis regresi linier berganda untuk masing-masing variabel baik secara parsial maupun simultan. Nilai $R$ Square $=0,357$ yang artinya pengaruh dari ketiga variabel sebesar 35,7\% selebihnya dipengaruhi oleh variabel lain.

Berdasarkan pembahasan dari tiga variabel tersebut dapat diambil kesimpulan bahwa variabel bebas berpengaruh terhadap variabel terikat dengan persentase $35,7 \%$ selebihnya $34,3 \%$ dipengaruhi oleh penelitian lain atau variabel lain. Sedangkan faktor yang dominan dari ketiga variabel yaitu variabel Kecelakaan Kerja (X3) dari pada variabel lainnya.

Dari hasil uji, dengan membandingkan nilai koefsien beta masing- masing variabel dapat diketahui variabel Kecelakaan Kerja memiliki nilai koefisien beta terbesar yaitu -0,299. Dengan nilai koefisien beta terbesar yaitu $-0,299$ dapat disimpulkan bahwa variabel Kecelakaan Kerja memiliki pengaruh yang paling dominan terhadap Pengaruh K3 Terhadap Produktivitas Pekerja pada proyek Pembangunan Laboratorium Komputer di Kabupaten Pamekasan.

\section{KESIMPULAN DAN SARAN}

- KESIMPULAN

Berdasarkan hasil dan pembahasan pada bab sebelumnya didapatkan kesimpulan sebagai berikut.

$\checkmark$ Dari hasil Uji t : Ketiga variabel tidak berpengaruh terhadap variabel (Y) yaitu Pengaruh Penerapan K3 terhadap Produktivitas Pekerja di Kabupaten Pamekasan khususnya pada Pembangunan Laboratorium Komputer di SMP It Al-Haromain, SMPS Darul Ulum, SMP Badrul Ulum.

$\checkmark$ Uji f : dengan membandingkan nilai koefsien beta masing- masing variabel dapat diketahui variabel Kecelakaan Kerja memiliki nilai koefisien beta terbesar yaitu -0,299. Dengan nilai koefisien beta terbesar yaitu $-0,299$ dapat disimpulkan bahwa variabel Kecelakaan Kerja memiliki pengaruh yang paling dominan terhadap Pengaruh K3 Terhadap Produktivitas Pekerja pada proyek Pembangunan Laboratorium Komputer di Kabupaten Pamekasan.

Uji Koefisen Determinasi Beganda dapat diketahui determinasi berganda $\left(\mathrm{R}^{2}\right)$ dari analisis regresi linier berganda untuk masing-masing variabel baik secara parsial maupun simultan. Nilai $\mathrm{R}$ Square $=0,357$ yang artinya pengaruh dari ketiga variabel sebesar $35,7 \%$ selebihnya dipengaruhi oleh variabel lain.

\section{- SARAN}

$\checkmark$ Dalam penelitian ini hanya menggunakan 3 variabel yaitu Keselamatan Kerja, Kesehatan Kerja dan Kecelakaan Kerja Untuk penelitian selanjutnya, perlu menambahkan variabel lain yang tidak masuk dalam penelitian ini, dan mungkin dapat memperoleh hasil yang lebih efisien.

$\checkmark$ Disarankan untuk tiap pekerjaan terutama bagi para kontraktor atau perencana menjaga keselamatan dan kesehatan agar tidak terjadi kecelakaan yang tidak di inginkan akbibat ke tidak pahaman tentang K3.

$\checkmark$ Disarankan penelitian ini dapat di lanjutkan untuk tiap pembangunan-pembanguna proyek khususnya di Kabupaten Pamekasan.

\section{DAFTAR PUSTAKA}

A.A. Anwar Prabu Mangkunegara. 2002.Manajemen Sumber Daya Manusia.Perusahaan. Bandung: PT. Remaja Rosdakarya.

Anies. Penyakit Akibat Kerja. Jakarta: PT Elex Media Komputindo; 2005.

Arikunto, S. 2006. Prosedur Penelitian Suatu Pendekatan Praktik Edisi Revisi VI. Jakarta : Rineka Cipta

AzmiD, Rahimah. 2009. Penerapan Sistem Manajemen Keselamatan dan Kesehatan Kerja oleh P2K3 Untuk Meminimalkan Kecelakaan Kerja di PT. 
Wijaya Karya Beton Medan Tahun 2008. (di

akses pada bulan Desember 2012)

(http://repository.usu.ac.id).

Candra, Lian. (2016).Analisis Potensi Kecelakaan Akibat Kerja Dengan Prosedur Hazard Identification, Risk Assesment, and Determing Control (HIRADC) Di PT Aneka Adhilogam Karya.Surakarta: Universitas Muhammadiyah Surakarta.

Elvianthi Elsa, 2011. Penerapan Keselamatan Dan Kesehatan Kerja (K3) Di PT. Pembangunan Perumahan (PP) (Persero) Pada Proyek Pembangunan Fakultas Kedokteran UISU. Medan: Unimed

Santoso G. Manajemen Keselamatan dan Kesehatan Kerja. Jakarta: Prestasi Pustaka;2004.

Sedarmayanti. 2009. Tata Kerja dan Produktifitas Kerja; Suatu tinjauan dari Aspek Ergonomi Atau Kaitan Antara Manusia Dengan Lingkungan Kerjanya.Bandung: Mandar Maju.

Sugiyono. (2014). Metode Penelitian Pendidikan Pendekatan Kuantitatif, Kualitatif, dan R\&D. Bandung: Alfabeta

Tarwaka.2012.Dasar-dasar Keselamatan Kerja Serta Pencegahan Kecelakaan Di Tempat Kerja. Surakarta: Harapan Press

Tarwaka.(2016).Dasar-dasar Keselamatan Kerja Serta Pencegahan Kecelakaan Di Tempat Kerja. Surakarta: Harapan Press 


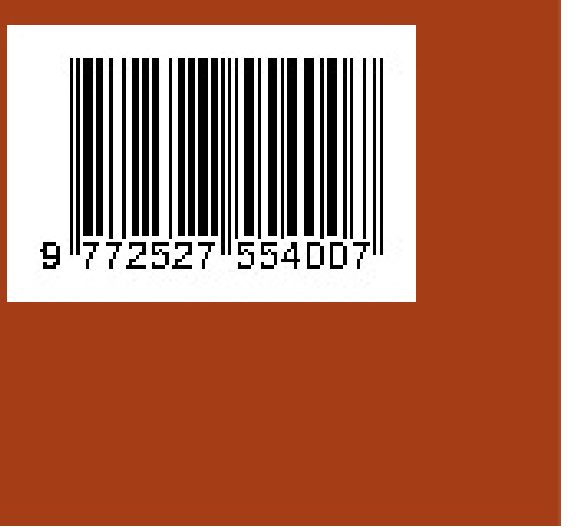

